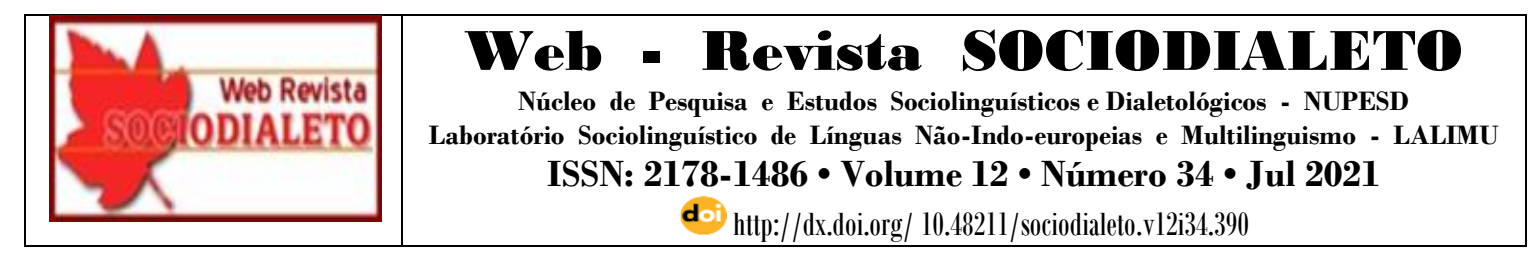

\title{
A LÍNGUA POMERANA DO RIO GRANDE DO SUL: REVISÃO DE LITERATURA
}

THE POMERANIAN LANGUAGE OF RIO GRANDE DO SUL: LTERATURE REVIEW

\author{
Bernardo Kolling Limberger (UFPel) ${ }^{1}$ \\ limberger.bernardo@gmail.com
}

Felipe Bilharva da Silva (SESIRS) ${ }^{2}$

felipebilharva@yahoo.com.br

Gabriela Wally Griep (UFPel) $)^{3}$

gabywgriep@gmail.com

Elizandra da Silva Netto (UFPel) ${ }^{4}$

elizandra.netto@gmail.com

\begin{abstract}
RESUMO: O pomerano é uma língua minoritária brasileira trazida por imigrantes das terras baixas da região do Mar Báltico há quase 170 anos. A língua é falada em seis estados do Brasil, predominando no Espírito Santo e no Rio Grande do Sul. Motivados pela pesquisa de Tressmann (2006a, 2006b, 2008), os estudos e as iniciativas de manutenção da língua surgiram no estado do ES e têm influenciado também a pesquisa feita em outros estados. O objetivo deste trabalho é verificar o estado da arte da pesquisa linguística que envolve o pomerano do RS. Para tanto, estabeleceu-se como método a revisão da literatura, buscandose, em bases de dados, artigos científicos completos, dissertações de mestrado e teses de doutorado por meio da palavra-chave "pomerano", sem estabelecer restrição quanto ao ano de publicação. Foram encontrados 20 estudos que se encaixaram nos critérios da revisão. Os resultados da revisão revelam diferentes possibilidades de investigação sobre uma língua. Por outro lado, apontam lacunas relacionadas principalmente à descrição do pomerano falado no RS, à escrita e às políticas linguísticas. Estudos sobre o pomerano e o bilinguismo/multilinguismo no qual ele está inserido são essenciais para criar estratégias de manutenção da língua, uma preocupação pertinente para manter sua vitalidade.
\end{abstract}

PALAVRAS-CHAVE: Pomerano; Rio Grande do Sul; Estudos linguísticos; Bilinguismo.

ABSTRACT: Pomeranian is a minority language which was brought to Brazil by the immigrants from the lowlands of the Baltic Sea region almost 170 years ago. The language is spoken in six Brazilian states, predominantly in Espírito Santo and Rio Grande do Sul. Motivated by Tressmann's research (2006a, 2006b, 2008), studies and language maintenance initiatives have emerged in the state of ES and have also influenced the research carried out in other states. The aim of this work is to verify the state of the art of

\footnotetext{
${ }^{1}$ Mestre e doutor em Letras (área de concentração: Linguística) pela Pontifícia Universidade Católica do Rio Grande do Sul (PUCRS). Professor da Universidade Federal de Pelotas e líder do grupo de pesquisa Laboratório de Psicolinguística, Línguas Minoritárias e Multilinguismo (Laplimm).

2 Mestre pela Universidade Federal de Pelotas (UFPel) e doutor em Letras (área de concentração: Linguística) pela PUCRS.

${ }^{3}$ Mestranda em Letras (área de concentração: Aquisição, Variação e Ensino) pela UFPel.

${ }^{4}$ Graduanda em Letras Português e Alemão pela UFPel.
} 


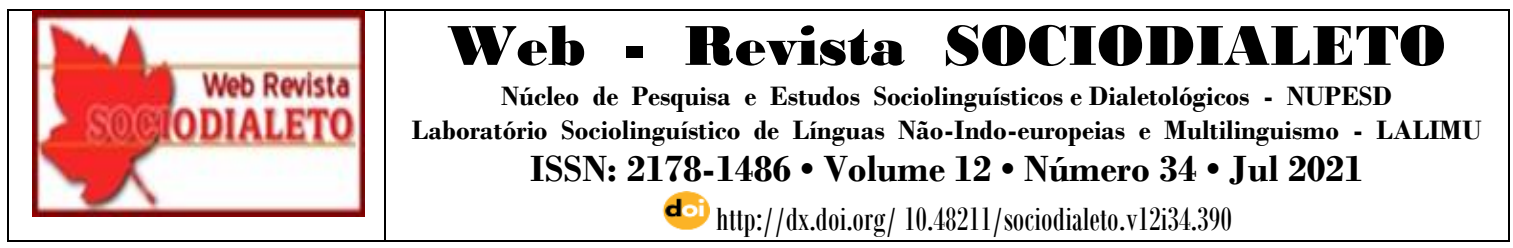

linguistic research that involves the Pomeranian in RS. To this end, the literature review was established as a method, the searching was performed in databases, complete scientific articles, master's, and doctoral works, through the keyword "Pomeranian", without establishing restrictions on the year of publication. Twenty studies were found that fit the review criteria. The results of the review display different possibilities of research about a language. Yet, they point to gaps related mainly to the description of the Pomeranian spoken in RS, to writing and to linguistic policies. Studies on Pomeranian and bilingualism/multilingualism in which it is inserted, are essential to create strategies for maintaining the language, a pertinent concern to maintain its vitality.

KEYWORDS: Pomeranian; Rio Grande do Sul; Linguistic studies; Bilingualism.

\section{Introdução}

O Brasil possui uma diversidade linguística que inclui línguas de imigração, indígenas, de sinais e afrobrasileiras, além de diferentes variedades do português. O nosso país tem 238 línguas, sendo 218 línguas vivas (EBERHARD; SIMONS; FENNIG, 2021). O pomerano, a língua focalizada neste trabalho, é uma das 13 variedades linguísticas pertencentes ao grupo alemão faladas no Brasil (ALTENHOFEN, 2013). Apesar da riqueza que caracteriza a nossa diversidade linguística, a condição de "dialeto", conforme afirma Altenhofen (2004), situado abaixo de uma norma standard, deu margem a uma gama de valorações depreciativas às línguas minoritárias em geral.

O pomerano tem, atualmente, status de língua brasileira, cooficializada em oito municípios e em processo de cooficialização em dois (IPOL, 2020). O status do pomerano como língua (não como dialeto) está sendo cada vez mais conhecido entre as comunidades pomeranas, e isso possibilita que os falantes tenham uma atitude mais positiva sobre a língua. Como dizem os pomeranos, "dai Pomerisch språk is balt set hunnerd sijbsig jår in Brasilien fortelt" (a língua pomerana é falada há quase 170 anos no Brasil) ${ }^{5}$. No contexto brasileiro, o pomerano é uma língua de imigração originária das terras baixas da região do Mar Báltico (TRESSMANN, 2008), falada em seis estados.

A localização geográfica dos falantes de pomerano está refletida na pesquisa sobre a língua. Motivados pelos estudos de Tressmann (2006a, 2006b, 2008), os estudos e as iniciativas de manutenção da língua surgiram no estado do Espírito Santo (ES). Faz-se

\footnotetext{
${ }^{5}$ Frase escrita de acordo com as normas ortográficas propostas por Tressmann (2006) e Schneider (2019).
} 


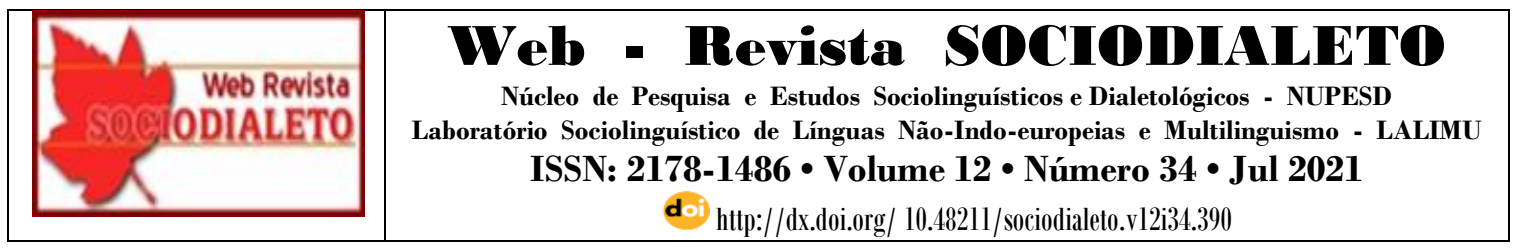

necessário verificar, portanto, o desenvolvimento de estudos sobre a língua no Rio Grande do Sul (RS), onde há, também, muitos falantes. A revisão de literatura pode revelar lacunas e apontar as possibilidades de pesquisa mais urgentes.

Nesse sentido, o objetivo deste trabalho é verificar o estado da arte da pesquisa linguística que envolve o pomerano do RS. Para atingirmos esse objetivo, o método consistiu numa revisão da literatura. Com a palavra-chave "pomerano" e sem restrição a um período específico de publicação, fizemos uma busca por artigos científicos completos, dissertações de mestrado e teses de doutorado em bases de dados.

Primeiramente abordamos, de forma geral, características do pomerano falado no Brasil. Em seguida, apontamos os caminhos metodológicos para atingirmos o objetivo. Depois disso, são apresentados e discutidos os estudos selecionados para análise e as considerações finais.

\section{O pomerano ${ }^{6}$}

O pomerano, segundo Tressmann (2008), é uma língua originária das terras baixas da região do Mar Báltico. Por isso, o autor caracteriza essa língua minoritária como baixo-saxônica, assim como o westfaliano, o Plautdietsch menonita, o Plattdeutsch, o neerlandês, entre outras. Todas essas línguas têm origem germânica, mas o pomerano é, para Tressmann (2008), uma língua originária do saxão antigo, da mesma forma que o inglês, que tomou outro caminho. Entretanto, conforme Beilke (2016), carecem estudos nos diversos níveis linguísticos que apresentem evidências que validem a própria etimologia do pomerano, que teria surgido de vários dialetos. Beilke (2016) argumenta que o pomerano estaria vinculado ao baixo-alemão, uma das variedades das terras planas do norte da Europa, podendo ser denominado lá como Pommersches Plattdeutsch, devido

\footnotetext{
${ }^{6}$ Não faz parte do escopo e do objetivo deste texto a caracterização detalhada da língua pomerana com relação à sua distribuição geográfica, história e aspectos linguísticos. Para detalhes a respeito, sugerimos conferir os textos citados. Esta seção é um resumo sobre a língua para embasar a revisão de literatura, foco do presente estudo.
} 


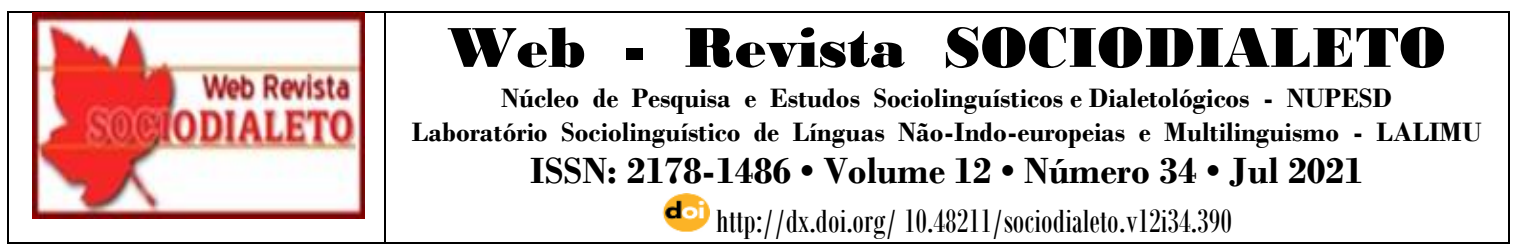

às semelhanças entre a variedade alemã e a brasileira. No Brasil, o pomerano é uma das 13 variedades linguísticas pertencentes ao grupo alemão (ALTENHOFEN, 2013).

A língua pomerana foi trazida pelos imigrantes provindos da Pomerânia a partir da década de 1850 (TRESSMANN, 2008). Segundo o mesmo autor, o povo pomerano também emigrou para os Estados Unidos e a Austrália. A província da antiga Prússia se localizava, segundo Tressmann (2008), entre as atuais Alemanha e Polônia (Figura 1).

Figura 1 - Mapa da antiga província da Pomerânia com destaque à linha Oder-Neisse (fronteira entre as atuais Alemanha e Polônia)

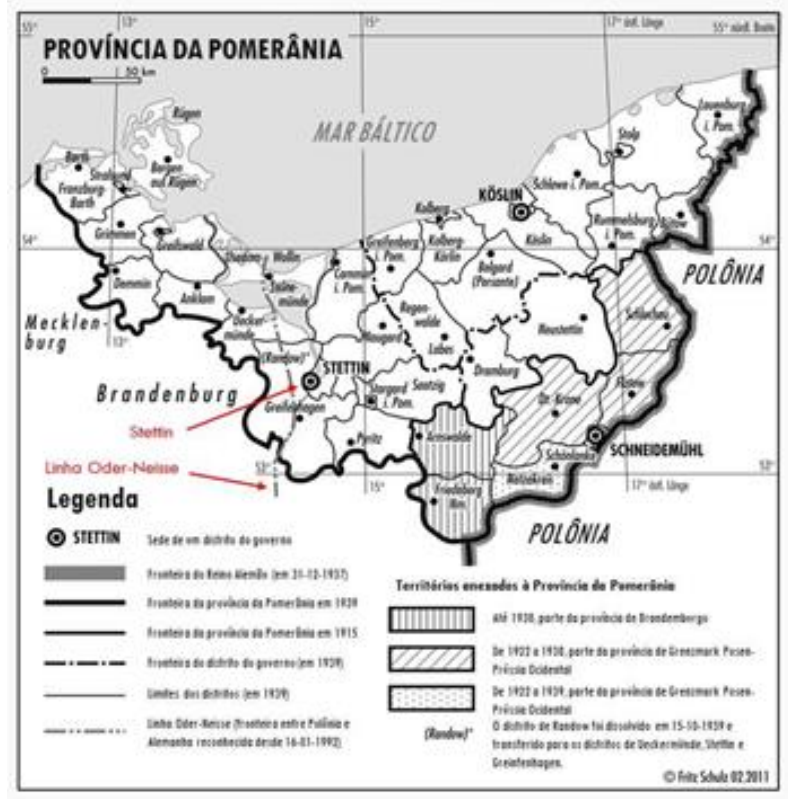

Schulz (2011, tradução de Bilharva da Silva, 2019, p. 38)

Na Figura 1, conforme relata Bilharva da Silva (2019), pode-se observar que a linha Oder-Neisse marcava a divisa entre a Pomerânia Ocidental e a Pomerânia Oriental. A capital da Pomerânia, Stettin, também está marcada no mapa. Conforme Tressmann (2008), a Pomerânia desapareceu do mapa com esse nome devido à derrota da Alemanha na II Guerra Mundial, e a linha Oder-Neisse passou a ser a fronteira entre a Alemanha e a Polônia. Depois disso, o pomerano se tornou uma língua moribunda, inclusive porque a maior parte da antiga Pomerânia se situa na Polônia. Uma característica da história linguística do povo pomerano, segundo Bilharva da Silva (2019), é a resistência em aderir 


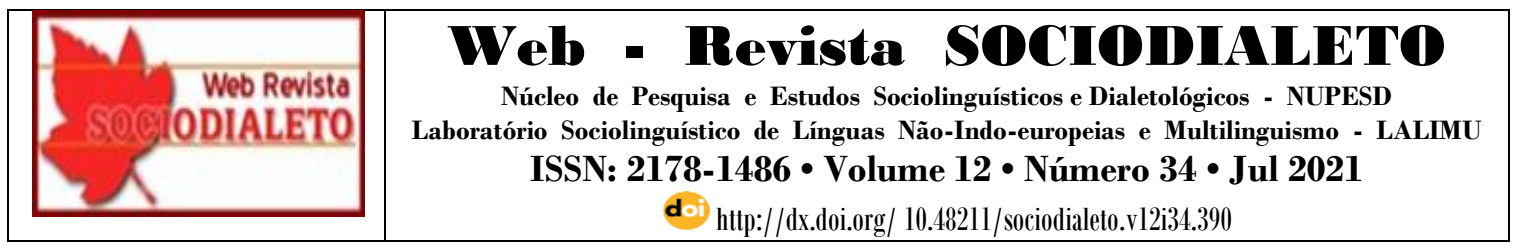

ao alto alemão (Hochdeutsch), língua que estava em fase de padronização na época da emigração. Essa característica certamente influenciou o uso da língua pomerana no Brasil.

A língua alemã standard é uma língua originária do Althochdeutsch (alto alemão antigo). Por isso, como salienta Tressmann (2008), o pomerano não é descendente do alemão, apesar de ambas as línguas pertencerem à mesma família linguística e terem muitos cognatos germânicos. Alguns exemplos são "cão" e "vidro", que são, respectivamente, "Hund" e "Glas" em ambas as línguas. Ambas as palavras também têm cognatos na língua inglesa: "glass" e "hound". A vinculação da língua pomerana à família germânica e à Prússia explicam a identificação dos pomeranos brasileiros com a cultura germânica e não eslava (BILHARVA DA SILVA, 2019). Contudo, conforme Beilke (2016), a grafia sugerida por Tressmann (2006) para o pomerano se distancia mais da grafia do alemão, aproximando-se, em alguns casos, do dinamarquês com caracteres escandinavos (a letra å, por exemplo) e terminações suecas.

Atualmente, segundo Tressmann (2008), fala-se pomerano nos seguintes estados do Brasil (Figura 2): Espírito Santo (ES), Rio Grande do Sul (RS), Santa Catarina (SC), Paraná (PR), Minas Gerais (MG) e Rondônia (RO). Os números de falantes de pomerano no Brasil não são consensuais: uma estimativa que encontramos indica 300.000 pessoas (EBERHARD; SIMONS; FENNIG 2021); outra, 200.000 (KAUFMANN et al., 2019). Não há como estabelecer números precisos, porque esses dados não são computados em censos no Brasil. Embora a língua seja falada nesses estados, ela predomina nos estados de ES, RS e SC.

Figura 2 - Mapa do Brasil com a localização dos estados brasileiros que possuem comunidades falantes de pomerano. Em destaque (verde), o estado do Rio Grande do Sul 

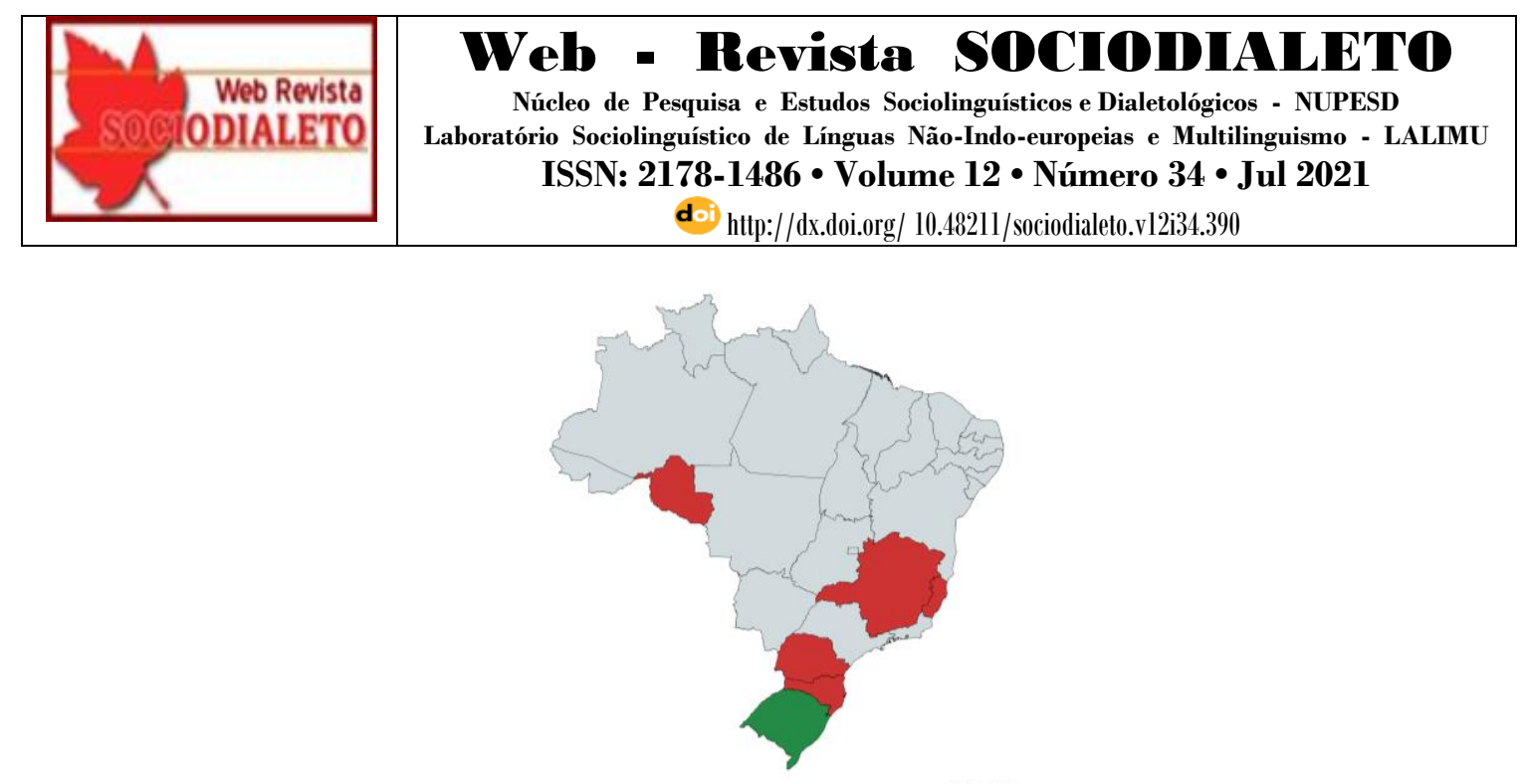

Fonte: os autores, elaborado com o MapChart

No RS, especificamente na Serra dos Tapes, a colonização pomerana iniciou em 1856 (SALAMONI; WASKIEVICZ, 2013). É exatamente nessa região onde há mais falantes de pomerano. Atualmente, há mais comunidades de falantes de pomerano em Arroio do Padre, Canguçu, Pelotas, São Lourenço do Sul e Turuçu, cidades localizadas no sul do estado.

Até a campanha de nacionalização do presidente Getúlio Vargas a partir de 1937 (ALTENHOFEN, 2013), a língua foi mantida nessas comunidades quase intacta, devido a diferentes fatores, que são abordados nos estudos revisados. Depois disso, houve um decréscimo gradual no número de falantes, aumento do uso do português e a negação dos direitos linguísticos (FOERSTE; BORN; DETTMANN, 2019). Atualmente, as comunidades se configuram como bilíngues (cf. GROSJEAN, 2010), uma vez que muitos falantes, especialmente os mais velhos, usam as duas línguas no cotidiano.

O status do pomerano, língua minoritária e, por vezes, desprestigiada no Brasil, tem mudado nas comunidades. Nos últimos anos, tem ocorrido um aumento de domínios de uso da língua, com a internet ${ }^{7}$ e o rádio $^{8}$ (BEILKE, 2016). Além disso, surgiram projetos, como o Proepo (Programa de Educação Escolar Pomerana), criado em 2005 no

\footnotetext{
${ }^{7}$ Por exemplo: Canal Pomeranos TV no YouTube, disponível em https://www.youtube.com/channel/UCjNyASiM01CxitM70Xx7TeQ. Acesso em: 03 abr. 2020. Grupo no Facebook: Up Pomerisch Srijwe un Leese lëre, disponível em: https://www.facebook.com/groups/607376165944848. Acesso em 14 out. 2020.

${ }^{8}$ Por exemplo, o programa Ümer Lustig, veiculado na Pomerisch Radio, conforme reportagem disponível em: http://www.testonoticias.com.br/geral/programa-\%C3\%BCmer-lustig-1.1989411. Acesso em 18 nov. 2020.
} 


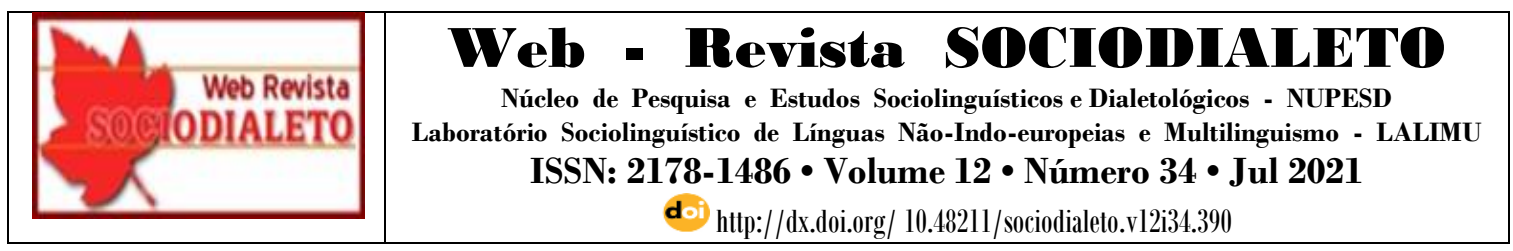

ES (FOERSTE; BORN; DETTMANN, 2019), com a consultoria do linguista Ismael Tressmann (2008). Nesse projeto, vários temas nas escolas podem abordados em pomerano, nas modalidades oral e escrita ${ }^{9}$. Assim, a língua passou a ser ensinada nas escolas e a ser usada na escrita, favorecendo a sua manutenção. Estudos mais atuais confirmam a importância do projeto para a valorização da cultura e língua pomerana no ambiente escolar bilíngue (FOERSTE; BORN; DETTMANN, 2019; KÜSTER, 2015).

Quanto ao ensino do pomerano no RS, encontramos relatos dos projetos Pomerando (KUHN, 2014) e Pomervida (NEUENFELDT, 2016), realizados em São Lourenço do Sul, e da inserção da disciplina de pomerano no currículo em Canguçu (SCHWARTZ, 2020). Certamente, o Proepo inspirou essas iniciativas, como relatado por Neuenfeldt (2016).

Juntamente com a inserção do pomerano na escola, cada vez mais municípios cooficializam a língua. Dois municípios do ES alcançaram a cooficialização do pomerano em 2008 (TRESSMANN, 2009). Atualmente, segundo o Instituto de Investigação e Desenvolvimento em Política Linguística (IPOL, 2020), ao todo, seis municípios do ES conseguiram cooficializar a língua, além de Pomerode (SC) e Canguçu (RS) e do processo em São Lourenço do Sul (RS). Por meio da cooficialização, segundo Tressmann (2008), o pomerano tem, ao lado do português, todos os direitos de uma língua oficial. Desse modo, a língua minoritária pode ter mais espaço e voz, não ficando restrita a contextos mais informais e caseiros.

No último ano, foi publicada uma lei no RS que reconhece a língua pomerana como de relevante interesse cultural: "Ficam reconhecidas como de relevante interesse cultural do Estado do Rio Grande do Sul a Cultura e a Língua Pomerana, falada e escrita" (RIO GRANDE DO SUL, 2020, p. 1). Essa lei está motivando a realização de ações para a manutenção do pomerano com a perspectiva de cooperação com uma universidade alemã. Outras iniciativas gaúchas estão relacionadas ao Colegiado da Diversidade Linguística do Rio Grande do Sul, criado no âmbito da política de fomento e salvaguarda

\footnotetext{
${ }^{9}$ Conforme relato disponível em: https://www.youtube.com/watch?v=UlBPvjh8hrA. Acesso em 01 jun. 2020 .
} 


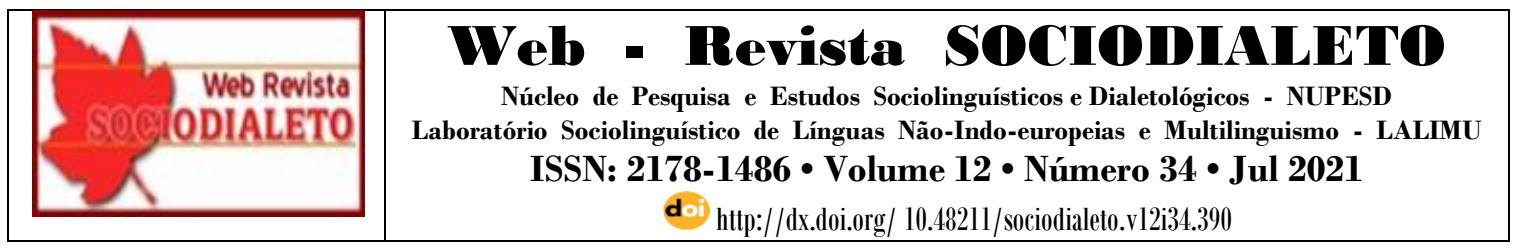

dos bens culturais de nosso Estado (COLEGIADO, 2018). As ações visam à preparação de um planejamento estratégica para propor e reivindicar um conjunto de ações e decisões que tem quatro pilares de sustentação: inventariar, reconhecer, salvaguardar e promover as línguas no estado.

Todas essas iniciativas contribuem para a consolidação da escrita do pomerano, uma variedade linguística essencialmente oral. Com o intuito de normatizar a escrita do pomerano, Tressmann (2006) desenvolveu o Dicionário Enciclopédico Pomerano (2006), que possui 16.000 verbetes e 560 páginas. O mesmo autor também publicou a coletânea de textos de autores de origem pomerana "Upm Land - Up pomerisch språk” - Na roça: em língua pomerana (TRESSMANN, 2006b). Além disso, temos acesso a um dicionário escolar recente com a ortografia atualizada da língua (SCHNEIDER, 2019) e ao curso online de pomerano "A língua pomerana além das fronteiras", promovido pela Secretaria de Estado da Cultura e pelo Fundo de Cultura do Estado do $\mathrm{ES}^{10}$. Há também iniciativas mais informais, como páginas e grupos do Facebook e do WhatsApp.

As práticas de escrita podem fornecer à língua minoritária mais visibilidade. Os pomeranos do RS e dos outros estados (especialmente do ES) têm se esforçado para fortalecer a sua língua e cultura. Uma prática tem sido o PomerBR ${ }^{11}$, encontro para debate e produção de materiais. Observa-se, dessa forma, a unificação do povo pomerano, resultado também das suas lutas por territórios com outros povos e outras comunidades tradicionais no Brasil (FOERSTE; BORN; DETTMANN, 2019). Além dessas iniciativas, na última década, até mesmo a pesquisa internacional tem dado visibilidade à língua pomerana do Brasil (p. ex., KAUFMANN, 2017; KAUFMANN et al., 2019; KAUFMANN; DURAN, 2021; POSTMA，2014; MORENO; GABRIEL，2020; ROSENBERG, 2020). Somente os estudos de Göz Kaufmann investigam o pomerano falado no RS.

Em suma, o pomerano é uma língua, embora seja considerada, frequentemente, por seus falantes e não falantes como "dialeto". A língua faz parte da diversidade

\footnotetext{
${ }^{10}$ Disponível em: https://ead.pomer.com.br/course/curso-de-pomerano/. Acesso em: 01 abr. 2020.

11 Para mais informações, pode-se verificar o site do PomerBR. Disponível em: http://pomerbr.blogspot.com. Acesso em: 01 abr. 2020.
} 


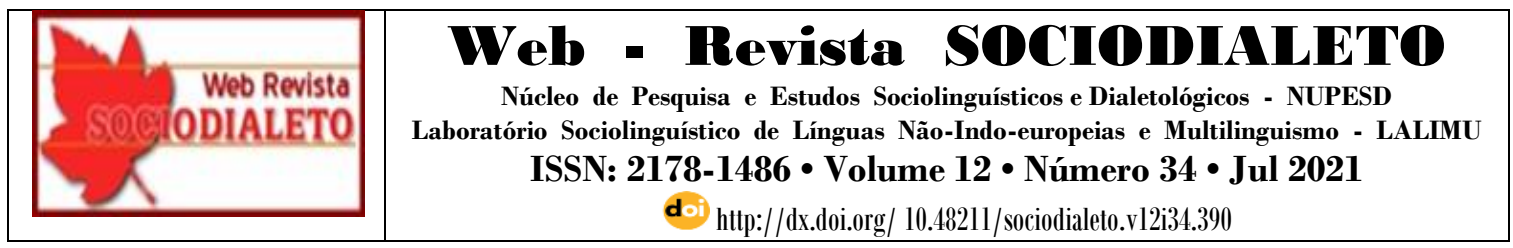

linguística brasileira e não se situa abaixo do português nem do alemão standard, ou seja, assume características próprias que são diferentes da sua origem. Conforme Savedra e Mazzelli-Rodrigues (2017), nas comunidades do ES, o pomerano, língua brasileira de imigração do século XIX, mantém a sua vitalidade, pois é usado por grande parte da população. Podemos dizer que essa afirmação também é válida para muitas comunidades pomeranas do RS. As autoras endossam a tese de que o pomerano pode ser considerado uma língua (neo)autóctone brasileira, pois as pessoas de Santa Maria de Jetibá (ES), por exemplo, já se autodenominam autóctones. As autoras citam argumentos relacionados ao tempo de uso do pomerano no Brasil, à nacionalidade brasileiras dos pomeranos e à vinculação à cultura e ao território do Brasil, problematizando, assim, o conceito de autoctonia.

\section{Método}

O objetivo deste estudo é verificar o estado da arte da pesquisa linguística que envolve o pomerano do RS. Para atingir esse objetivo, o método consistiu numa revisão da literatura. Com a palavra-chave "pomerano" e sem restrição a um período específico de publicação, fizemos uma busca por artigos científicos completos, dissertações de mestrado e teses de doutorado. Utilizamos os seguintes mecanismos de busca: Catálogo de Teses e Dissertações da Capes, Portal de Periódicos Capes e Google Acadêmico.

Depois da leitura dos títulos e dos resumos dos textos encontrados e discussão entre os autores, selecionamos aqueles que abordam a língua pomerana do RS. Excluímos os trabalhos repetidos ou derivados das teses ou dissertações selecionadas, além dos estudos sobre a língua pomerana de outros estados e/ou outras questões pomeranas, como cultura, história, antropologia e turismo. Reportamos e discutimos os estudos selecionados com relação aos objetivos, ao método, aos resultados e à sua contribuição para a compreensão da língua pomerana no RS e do bilinguismo/multilinguismo que envolve essa língua. 


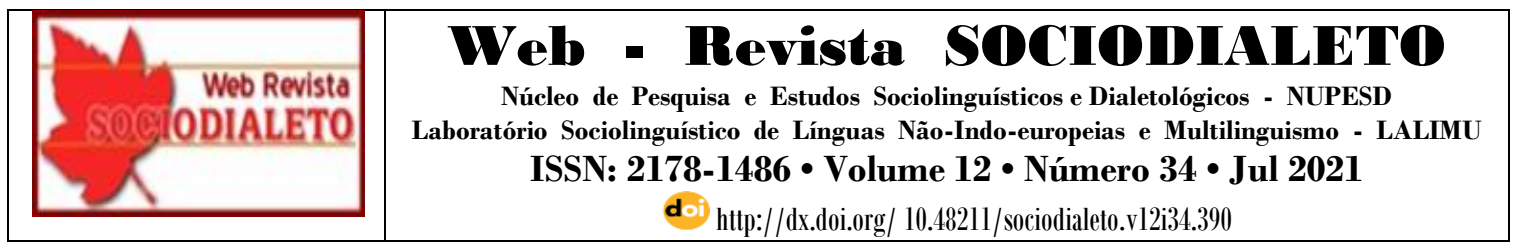

\section{Resultados e discussão}

A busca no Catálogo de Teses e Dissertações da Capes resultou em 46 textos. Após a aplicação dos critérios de inclusão, foram selecionadas 13 teses e dissertações. No Google Acadêmico, a busca identificou 933 artigos, dos quais cinco atenderam aos critérios. Por fim, a busca no Portal de Periódicos Capes resultou em 51 textos, mas nenhum deles atendeu aos critérios. Além desses trabalhos, incluímos um estudo do nosso banco de dados, ou seja, um estudo estrangeiro que não tinha sido encontrado nas buscas (KAUFMANN, 2017) e um estudo que foi publicado depois da realização das buscas (MOZZILLO; SPINASSÉ, 2020).

Na sequência, os 20 estudos sobre a língua pomerana e o bilinguismo envolvendo essa língua são reportados e discutidos considerando: objetivos, métodos, resultados e contribuições. Para facilitar a organização e a compreensão dos estudos encontrados, eles foram divididos em cinco grandes categorias temáticas: estudos com foco na língua pomerana $(n=2)$; estudos sobre as línguas em contato $(n=8)$; estudos sobre ensino e aprendizagem de pomerano $(n=2)$; estudos fonético-fonológicos $(n=5)$ e estudos psicolinguísticos $(n=3)$. É importante ressaltar que essas categorias, elaboradas com propósitos didáticos, não são estanques, pois há estudos que perpassam mais de uma categoria, investigando aspectos diversos da língua pomerana e do bilinguismo.

\subsection{Estudos com foco na língua pomerana}

Dois dos estudos encontrados investigam aspectos da língua pomerana usada no RS (BEILKE, 2016; KAUFMANN, 2017), embora abordem igualmente a variedade falada no ES e em MG. A abordagem do pomerano falado em outros estados do Brasil, aliás, é predominante nos estudos da língua (por exemplo, MORENO; GABRIEL, 2020; POSTMA, 2014; SAVEDRA; MAZZELLI-RODRIGUES, 2017; TRESSMANN, 2006a, 2006b, 2008, 2009), motivo que ressalta a relevância do presente trabalho.

A dissertação de mestrado de Beilke (2016) teve como objetivo realizar a compilação de corpora do pomerano no Brasil, ou seja, coletar e categorizar materiais 


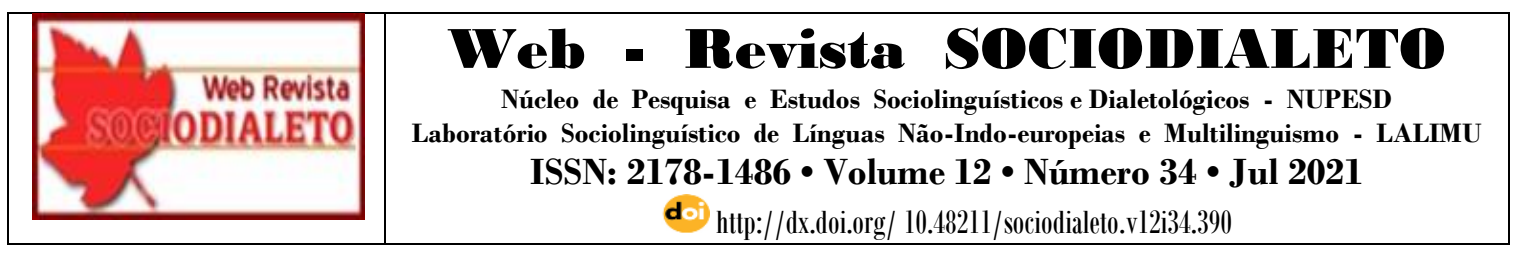

autênticos nessa língua. Para tanto, foram selecionados dados de pomerano escrito (de diversas fontes) e oral (coletados por meio de 20 interações face-a-face, baseadas em questionários). As coletas foram realizadas em MG e no RS, estado no qual foram selecionados os municípios de Arroio do Tigre e Vera Cruz, situados no Vale do Rio Pardo. Além das coletas, foram adicionadas letras de músicas, lembranças, anotações e receitas culinárias doadas por pomeranos em cidades como Canguçu e São Lourenço do Sul. A escolha dos estados do RS e de MG justifica-se, segundo a autora, pelo menor número de estudos realizados nessas regiões quando em comparação com ES e SC, constatação igualmente atingida em nossas buscas por estudos nas bases de dados.

Para a compilação dos corpora, houve diferentes tratamentos: transcrição, digitalização, digitação, conversão da escrita para o sistema de Tressmann (2006) e etiquetagem. Com relação às bases de dados escritos, suas fontes foram lápides, registros eclesiásticos, cartas pessoais, receitas culinárias, jornal Folha Pomerana, textos da internet, legendas de documentários, trabalhos acadêmicos, textos religiosos, letras de música pomerana, textos literários, livros, Sprüche (ditos populares) e palavras isoladas. A autora também encontrou textos literários antigos da Pomerânia. Com tantos materiais escritos, o estudo sustenta e comprova que o pomerano não é uma língua ágrafa.

Os principais resultados de Beilke (2016) indicam que, no Vale do Rio Pardo, o pomerano não é mais falado com regularidade, ao contrário de Canguçu. Com relação ao léxico empregado, na comparação entre as variedades de MG e RS, foi detectado um número expressivo de itens lexicais idênticos, embora haja também diferenças. Além disso, a pesquisadora identificou itens lexicais que evidenciam o contato do pomerano com outras línguas de origem alemã, como o hunsriqueano, e com o português. Os Pommersche Korpora, como a autora os nomeia, contribuem muito para a documentação da língua e para a compreensão do uso da língua nas comunidades selecionadas, além de serem importantes materiais para estudo lexical da língua falada e escrita.

Também considerando o léxico, o objetivo de Kaufmann (2017) foi analisar comparativamente três variedades germânicas do sul do Brasil: Plautdietsch menonita, hunsriqueano e pomerano. Para atingir esse objetivo, o pesquisador solicitou que os 


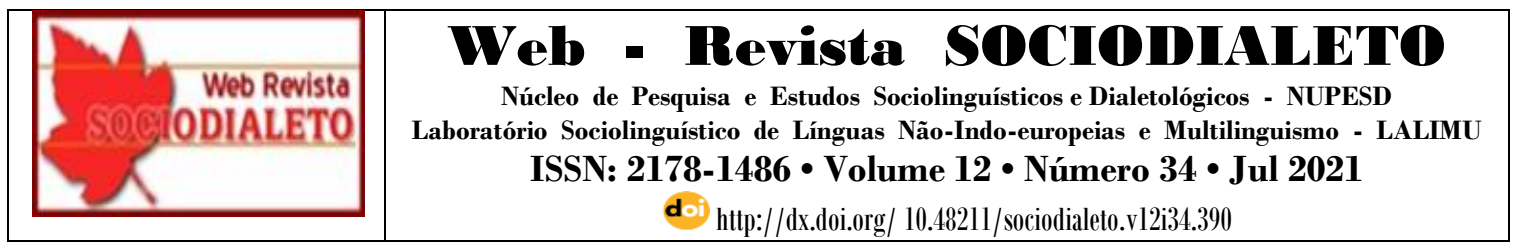

participantes traduzissem frases-estímulo do português para a língua-alvo e analisou os empréstimos e as hesitações durante a tradução. Os dados foram analisados com relação a diferentes características dos informantes. Dos 49 informantes falantes de pomerano, residentes nas comunidades de Canguçu e São Lourenço do Sul, 32,7\% têm o pomerano como língua dominante, $22,4 \%$ são bilíngues equilibrados e $44,9 \%$ têm o português como língua dominante. Quanto ao uso das palavras, o autor identificou que os empréstimos em pomerano aparecem até mesmo quando o termo existe em pomerano, como no caso de Bauk 'livro' (KAUFMANN, 2017, p. 4), para a qual a produção em português foi usada em $28,8 \%$ nas produções. Uma hipótese para tal emprego variável pode residir na intensa situação de contato linguístico existente nas comunidades, embora essa seja uma tendência para os informantes mais novos (em média, 28 anos). Tal processo de adaptação lexical ainda não está sacramentado, pois, no caso do referido item lexical, em cinco produções, os participantes realizaram reparos, ou seja, usaram primeiramente a palavra emprestada do português e, logo em seguida, usaram a palavra em pomerano. Foram verificadas pausas e produção de segmentos fonéticos mais longos, que podem indicar busca por item lexical alternativo. Fatores que podem ter influenciado o uso de empréstimos são a língua da escolarização, o português, no caso dos pomeranos, e a porcentagem de dominância em português, que é mais alta do que em pomerano. Uma contribuição relevante do estudo é mostrar, de forma comparativa, como as palavras (e as frases) estão sendo usadas nas diferentes comunidades, analisando esse uso com relação a diferentes variáveis.

Tanto o estudo de Beilke (2016) quanto o de Kaufmann (2017) têm como escopo de análise dados em pomerano do RS, produzidos em contexto autêntico e de coleta de dados. Dessa forma, fornecem exemplos do pomerano efetivamente falado no estado, sobretudo no nível lexical, mas também no sintático (KAUFMANN, 2017). Além disso, estudos sobre o uso da língua podem fornecer contribuir para a seleção de estímulos para experimentos sobre o processamento e a percepção da língua, além da formulação de materiais didáticos. O pomerano, conforme mostram os estudos, pode ser caracterizado como uma língua que apresenta variação e particularidades que o distinguem das línguas faladas na Europa, como o contato com outras línguas brasileiras e com a escrita em 


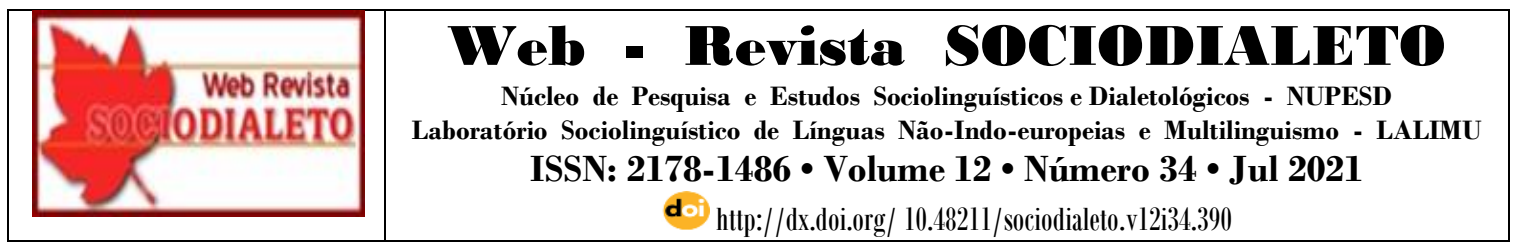

português. Especificamente sobre a escrita, o estudo de Beilke (2016) contribui para desmistificar a crença de que o pomerano não poderia ser escrito. O corpus de Beilke (2016) contribui muito para a documentação da língua e pode ser ampliado para outras comunidades gaúchas. Atualmente, as possibilidades de escrita são cada vez mais frequentes e diversas, pois seguem: a) os traços da família germânica, mais próximos ao alemão standard; b) as normas propostas por Tressmann (2006) para a escrita do pomerano moderno; c) as regras ortográficas do português; ou d) um modelo misto.

\subsection{Estudos sobre línguas em contato (pomerano-português)}

Entre os trabalhos localizados nas bases de dados consultadas, oito (VANDRESEN， 2006; VANDRESEN; CORRÊA， 2008; MUJICA， 2013; MACKEDANZ, 2016; SOUZA, 2017; VAHL, 2017; BERWALDT; THUM, 2018; MOZZILLO; SPINASSÉ, 2020) focalizam o contato linguístico. Por contato linguístico, estamos fazendo referência àqueles trabalhos que buscam "estudar as situações variadas de contato de línguas, os fenômenos resultantes do contato e a interação entre fatores linguísticos e extralinguísticos para a definição do resultado do contato" (WINFORD, 2003, apud MILESKI, 2017, p. 85). Tal área da sociolinguística ganhou particular interesse a partir do trabalho de Weinreich (1963 [1953]), segundo o qual "duas ou mais línguas serão denominadas em contato se forem utilizadas alternadamente pelas mesmas pessoas. Os indivíduos que utilizam as línguas são então o lócus do contato" (WEINREICH, 1963 [1953], p. 1).

Naturalmente, diante desse ponto de partida, podemos verificar que outros trabalhos discutidos neste artigo igualmente contemplam, em maior ou menor grau, o contato linguístico. Entretanto, nesta seção, reunimos aqueles que buscam descrever e discutir os contextos de uso de cada uma das línguas em contato nas comunidades pomeranas do RS, problematizando questões relacionadas à diglossia ou às identidades a elas vinculadas. Na sequência, discutimos os estudos encontrados, tomando como fio condutor a ordem cronológica de publicação. 


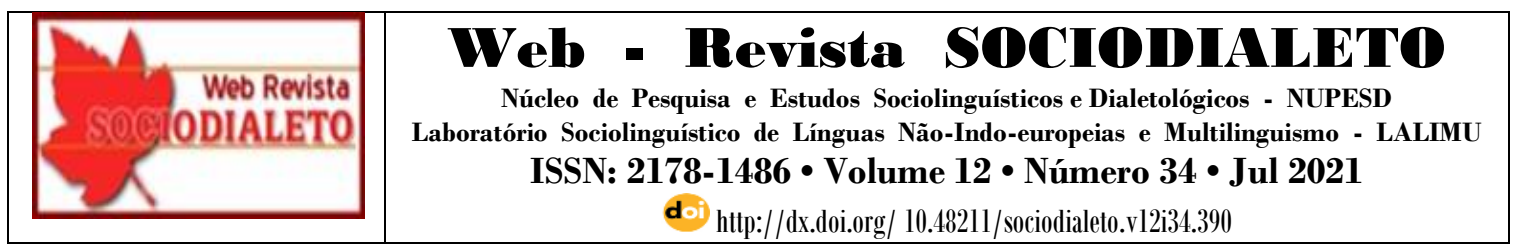

O primeiro trabalho que discutimos foi realizado por Vandresen (2006), que teve como foco o contato linguístico na comunidade de Arroio do Padre. A partir da aplicação de um questionário, o autor descreve a situação do bilinguismo na comunidade, verificando a presença do pomerano, as funções das línguas de contato e as atitudes de lealdade linguística. Para tanto, foram investigados três grupos etários: participantes com menos de 24 anos, com 25 a 50 anos e com mais de 50 anos. Os resultados do questionário revelaram que todos os 150 participantes falavam e entendiam pomerano e português na época. Em casa, todos os participantes mais velhos falavam pomerano, mas, entre os jovens de até 24 anos, verificou-se leve decréscimo no uso da língua, utilizando-a quase sempre com vizinhos e amigos, inclusive na venda e no armazém. Nas gerações de 25 a 50 anos e mais de 50 anos, o uso predominante era de pomerano, embora o autor apontasse para um avanço do uso de português. Por fim, dentro da comunidade, a maioria dos informantes declarou sua preferência pelo pomerano.

Apesar de os dados mostrarem o uso predominante do pomerano na comunidade, Vandresen (2006) afirma que, entre os alunos da $5^{\mathrm{a}}$ à $8^{\mathrm{a}}$ série, o português apresentava grau de uso crescente, o que poderia levar a uma mudança no lar em relação ao pomerano. A maioria das pessoas respondeu, entretanto, que continuaria falando pomerano dentro da comunidade. No entanto, o autor constatou que, nas funções internas, aquelas relacionadas à afetividade (MACKEY 2000), o pomerano estava perdendo terreno devido ao avanço da competência linguística no português. Esse trabalho mostra que a língua pomerana era, nos anos da pesquisa, a língua de preferência na comunidade de Arroio do Padre, sempre em situação de contato com o português.

O estudo de Vandresen e Corrêa (2008), por sua vez, teve como objetivo geral compreender aspectos do contato do pomerano com português em comunidades bilíngues de Pelotas e Arroio do Padre. Para tanto, foi aplicado um questionário a uma amostra de 120 participantes, sendo 60 de Arroio do Padre, residentes na área rural, e 60 de Pelotas, residentes em área urbana. Com relação às competências linguísticas dos informantes em pomerano, verificou-se que todos os participantes de Arroio do Padre, também nessa pesquisa, compreendiam e falavam pomerano, ao passo que, em Pelotas, 56 entendiam e 52 falavam a língua. Os dados revelaram um uso quase exclusivo do pomerano nos lares, 


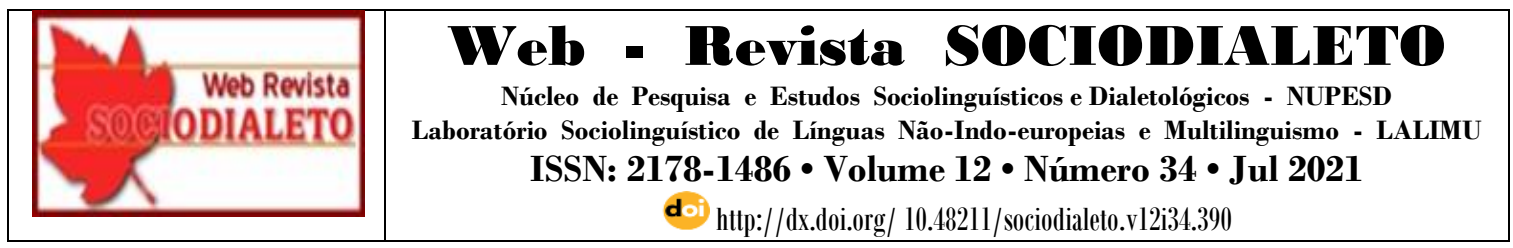

especialmente em Arroio do Padre. Já em Pelotas, na geração de até 24 anos, houve uma diminuição de uso do pomerano no lar. Quanto às atitudes linguísticas, os resultados demonstraram preferência pelo pomerano por 91,7\% dos moradores de Arroio do Padre e por $31,7 \%$ dos moradores de Pelotas. No que se refere à continuidade do pomerano nas comunidades, em Arroio do Padre, 59 dos 60 informantes julgaram que o pomerano continuaria a ser falado pelas futuras gerações. Os pelotenses também foram favoráveis a ensinar os filhos, mesmo os mais jovens, embora apenas 25 deles $(41,6 \%)$ julgaram que o pomerano sobreviveria na região. O estudo mostra que, apesar de haver bilinguismo em ambas as localidades, ocorre de maneira mais vigorosa na zona rural. Contudo, as atitudes linguísticas mostraram-se positivas nas comunidades, embora em diferentes níveis, demonstrando o interesse, pelo menos nos discursos, na manutenção da língua pomerana.

Também investigando o uso das línguas em contato e relações de prestígio e identidade, em sua dissertação de mestrado, Mujica (2013) teve como objetivo verificar se haveria uma situação diglóssica entre o pomerano e o português na comunidade de Santa Augusta em São Lourenço do Sul. Para tanto, a autora coletou práticas de fala de duas famílias da comunidade, selecionadas a partir de entrevistas prévias com crianças da turma pré-escolar da Escola Municipal de Ensino Fundamental Martinho Lutero. Os resultados das entrevistas com as famílias sugerem que o uso de pomerano prevalecia nas interações familiares e com vizinhos, na igreja, no trabalho, no campo, nas interações informais na escola e nas festas de comunidade. Ou seja, na maioria das vezes, em interações entre bilíngues, os entrevistados preferiam usar pomerano ao português. Além disso, os membros da comunidade entrevistados afirmaram perceber o valor e a importância da sua cultura, acreditando que o pomerano constitua um elemento forte dentro da comunidade, mas sem potencial para crescer fora dela. A autora pôde verificar, portanto, que a identidade dos participantes está mais associada à cultura pomerana, "visto que seus hábitos alimentares e seus costumes, com relação à decoração, aos horários, aos trabalhos na lavoura, às festas, entre outros, se assemelham mais aos seus antepassados do que à realidade dos brasileiros sem vínculos pomeranos." (MUJICA, 2013, p. 64). Dessa forma, a identidade pomerana revela-se mesmo no uso da língua 


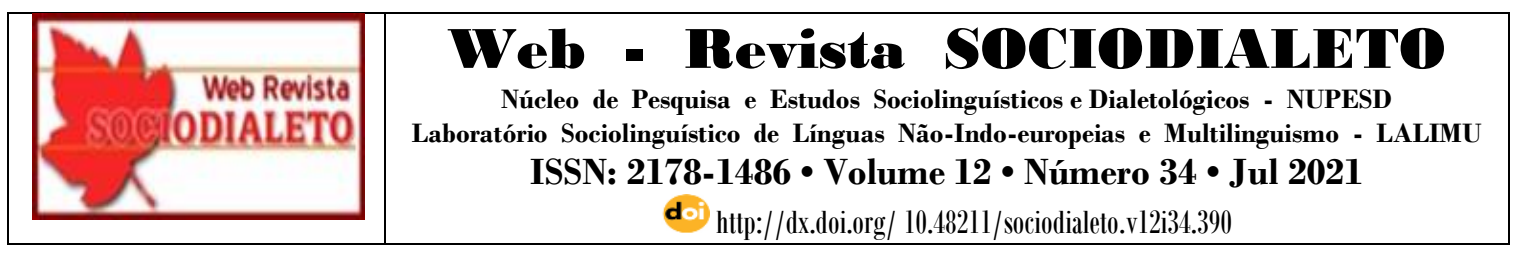

portuguesa, em que marcadores linguísticos do pomerano - como a entonação ascendente em finais de frases declarativas - são verificados.

Além do trabalho de Mujica (2013), a pesquisa de Mackedanz (2016) igualmente teve Santa Augusta, em São Lourenço do Sul, como comunidade-alvo. Nessa pesquisa, o objetivo foi investigar se e como o português influencia a manutenção do pomerano, bem como avaliar de que maneira essa língua minoritária pode influenciar a constituição da identidade dos falantes em contexto bilíngue escolar pomerano/português. O estudo foi realizado na mesma escola da pesquisa de Mujica (2013). Foram selecionados 21 alunos da pré-escola, sua professora e 29 estudantes do $9^{\circ}$ ano do ensino fundamental, constituindo, assim, 51 participantes. A coleta de dados ocorreu com observações de aulas, seminários sobre o uso das línguas e entrevistas com a direção, a professora e os alunos. Os resultados também apontam para uma situação de diglossia na comunidade, sendo que o pomerano é mais usado em ambientes informais, como o lar e o trabalho agrícola, nos quais os falantes aprendem a língua e se constituem socialmente no início da vida. Já nos ambientes formais, a autora pôde perceber que a escola se preocupa com a manutenção da cultura e da língua, pois atividades voltadas ao contexto sociocultural e linguístico dos alunos, como aulas de língua pomerana, são realizadas. Desse modo, a escola colabora para a valorização da identidade que os alunos trazem de casa. Porém, os resultados também mostram que há um processo gradual de substituição do pomerano, pois o português foi aos poucos sendo mais utilizado pela professora durante o ano letivo. O pomerano foi mais utilizado em interações aluno-aluno. Além disso, o número de alunos ingressantes que já falam português vem aumentando com o tempo, o que faz com que o uso dessa língua ocorra com mais frequência na escola. Com base nessas discussões, a autora conclui que a identidade pomerana relacionada às práticas informais contribui fortemente para a manutenção da língua.

Por sua vez, o estudo de Souza (2017) teve como foco a manutenção e revitalização do pomerano em Santa Maria de Jetibá (ES) e Canguçu (RS). Nesse estudo, os objetivos principais foram identificar quais fatores determinam a dinâmica de manutenção e/ou substituição da língua minoritária e entender quais ações de intervenção auxiliam na manutenção e na revitalização da língua. Para tanto, a pesquisa englobou 


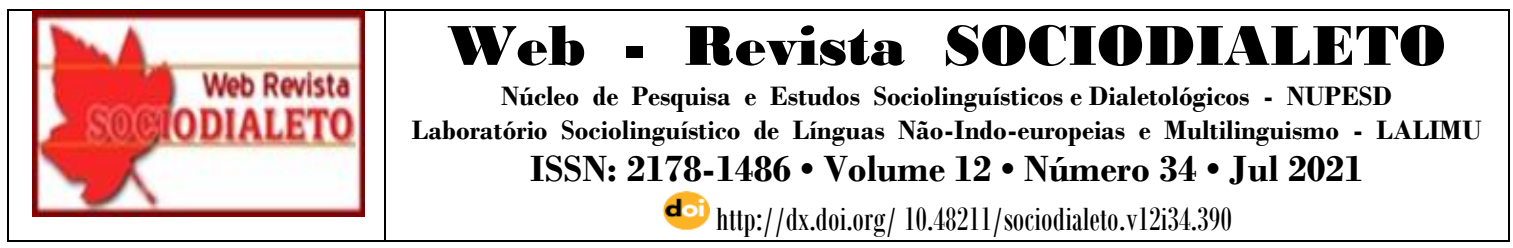

participantes tanto da zona rural quanto da urbana, em faixas etárias de 18 a 35 e acima de 48 anos, os quais foram divididos em grupos segundo a idade e a escolaridade - alta e baixa. Foi realizada uma entrevista com questionário envolvendo oito grupos organizados de acordo com diferentes dimensões (diatópica, diageracional, diastrática, dialingual e diafásica). Além desses grupos, foram realizadas mais quatro entrevistas, com dois gestores e dois servidores públicos, além de saídas de campo, para conhecer as comunidades, e visitas de observação em escolas para compreender a dinâmica pedagógica relacionada à manutenção e substituição linguística. Os resultados demonstram que, na dimensão diatópica, por haver uma crescente urbanização, o contato com o português vem aumentando, o que tem relação com os estudos anteriores. Mesmo na zona rural, a língua majoritária vem tomando cada vez mais espaço dentro das relações familiares, de trabalho ou sociais. Apesar disso, o pomerano ainda é recorrente nas casas, sendo a geração mais velha a maior responsável por sua manutenção. Também foi possível verificar que a maioria dos descendentes entrevistados mantém um nível de bilinguismo passivo, o que mostra que, mesmo sendo a língua mantida pela geração mais velha, corre risco de substituição pelo português, por parte da geração mais nova, da mesma foram que nos estudos de Vandresen (2006) e Vandresen e Corrêa (2008). O estudo demonstra que, mesmo que o pomerano seja fortemente mantido nas comunidades, a situação se encaminha para a redução linguística, principalmente pelos resultados encontrados na dimensão diageracional. O estudo mostra, ainda, que políticas de manutenção são necessárias no meio familiar, escolar (especialmente na geração mais nova) e de trabalho.

Na dissertação de Vahl (2017), o objetivo geral foi verificar como ocorre o codeswitching entre pomerano e português em um grupo de alunos do ensino médio da mesma escola na qual Mujica (2013) e Mackedanz (2016) realizaram as suas pesquisas. Foram analisadas as ocorrências de code-switching e as opiniões das famílias em relação ao uso da língua pomerana em contexto escolar. A metodologia adotada consistiu em observações, gravações e entrevistas sociolinguísticas com os alunos, professores e pais dos oito alunos investigados. Os resultados indicam motivações diversas para o uso de code-switching em aula, como marcar um efeito de comicidade e manter sigilo sobre algo. 


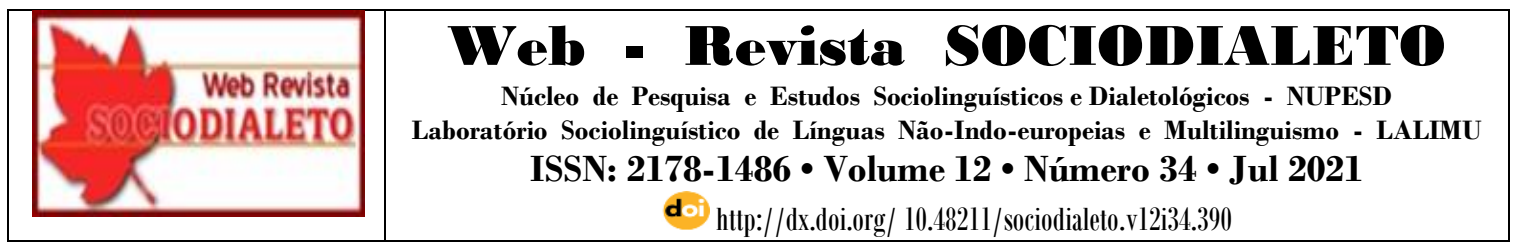

As ocorrências de code-switching não foram, portanto, limitadas à falta de conhecimento linguístico. Além disso, os alunos realizaram code-switching tanto com o professor bilíngue quanto com o professor não bilíngue, não havendo, portanto, distinção ou vergonha no uso do pomerano em sala de aula. A família parece desempenhar forte papel para o uso do pomerano pelos seus filhos (58\% dos alunos falam pomerano na escola), desempenhando um papel fundamental para a manutenção da língua. Vahl (2017) concluiu seu trabalho mencionando que os alunos, a partir da aceitação da língua pomerana na escola, estão aprendendo a conhecer, respeitar e manter a língua.

Berwaldt e Thum (2018) buscaram analisar as dimensões da cultura e da identidade a partir dos referenciais de língua materna das comunidades tradicionais pomeranas. O trabalho de campo ocorreu em três espaços com diferentes instrumentos de coleta: entrevistas com a comunidade da Serra do Tapes, observação em duas escolas da região e questionário aplicado com o público escolar. Os resultados indicam que $90 \%$ dos entrevistados aprenderam a falar pomerano com os avós, $90 \%$ utilizam a língua pomerana com a família, $60 \%$ utilizam a língua nos espaços escolares entre amigos e $60 \%$ afirmam que já sofreram ação de preconceito em função da língua. Esses dados impactam diretamente na evasão escolar em função do desprezo pela língua e pelo bullying. Os autores sugerem a necessidade de sensibilização cultural urgente nas escolas, valorizando questões sociolinguísticas, priorizando a condução das aulas por professores aptos a lidarem com os problemas de sala de aula. Nas observações feitas no diário de campo, verificou-se que havia dois meninos que não dominavam o português, sendo, por isso, tímidos e incompreendidos, mesmo sendo o pomerano uma língua cooficial em Canguçu. Dessa forma, os autores concluem que as práticas linguísticas integrativas são de grande importância para que os alunos possam sentir-se pertencentes ao espaço. Os autores chamam a atenção para a necessidade de desenvolver políticas públicas que sejam direcionadas para a cultura local e um currículo que acompanhe mudanças, fortalecendo as línguas minoritárias. Além disso, cremos ser importante oportunizar aos estudantes a aprendizagem da língua majoritária.

Por fim, Mozzillo e Spinassé (2020) investigaram políticas linguísticas familiares, isto é, práticas e decisões linguísticas de famílias plurilíngues, analisando as 


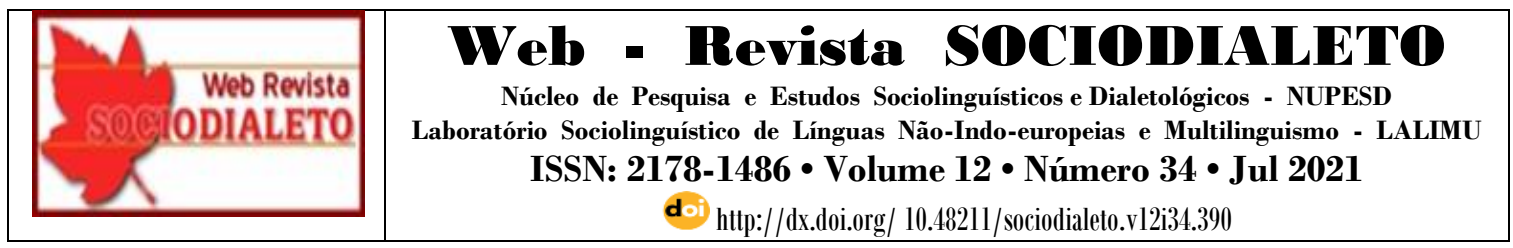

consequências que ideologias linguísticas produziram nas escolhas. Para tanto, aplicaram um questionário para 42 pessoas, falantes de diversas línguas. No artigo, analisam as respostas de cinco falantes de línguas minoritárias, dentre elas, Marta, uma falante de pomerano. Marta aprendeu português e pomerano precoce e simultaneamente (duas línguas maternas com peso semelhante). A língua mais falada em casa era o pomerano e, na escola, era o português, o que corrobora os estudos anteriores. Marta também relata preconceito em relação pomerano e ao seu sotaque; porém, ao retornar ao seu local de origem, a identidade pomerana aflorou e ela voltou a falar a língua. Essa identificação facilita a transmissão intergeracional da língua: Marta ensina pomerano ao seu filho. Segundo as autoras, ela é a que mais se dedica a transmitir sua língua entre os participantes do estudo, mostrando uma política linguística familiar mais propensa ao bilinguismo e uma atitude mais positiva sobre a língua de imigração. O estudo salienta a contribuição das ideologias linguísticas e das políticas linguísticas familiares para a manutenção das línguas.

Os estudos sobre contato linguístico do pomerano com o português e outras línguas contribuem para mostrar o uso das línguas nas comunidades gaúchas relacionado a fatores linguísticos e extralinguísticos, como idade, gênero, escolaridade e ideologias. Desde 2006, estudos têm evidenciado que o pomerano tem se tornado mais frequente nas comunidades mais rurais em comparação às comunidades urbanas, permanecendo também mais restrito a contextos informais. Souza (2017) salienta que a situação se encaminha para a redução linguística. A partir dos estudos e de observações que fizemos, verificamos que a língua é aceita nas escolas, especialmente na Escola Martinho Lutero, como prática de integração das crianças da comunidade, embora essa prática reduza com o passar dos anos escolares (MUJICA, 2013; MACKEDANZ, 2016; VAHL, 2017; BERWALDT; THUM 2018).

Dessa forma, no que concerne às questões sociais envolvendo o contato linguístico pomerano-português no RS, parecem coexistir dois discursos principais, ao mesmo tempo dissonantes e complementares. Por um lado, verifica-se, em alguns estudos, relatos de preconceito linguístico, substituição linguística e bilinguismo passivo nas comunidades; apesar disso, por outro lado, são recorrentes os discursos pela 


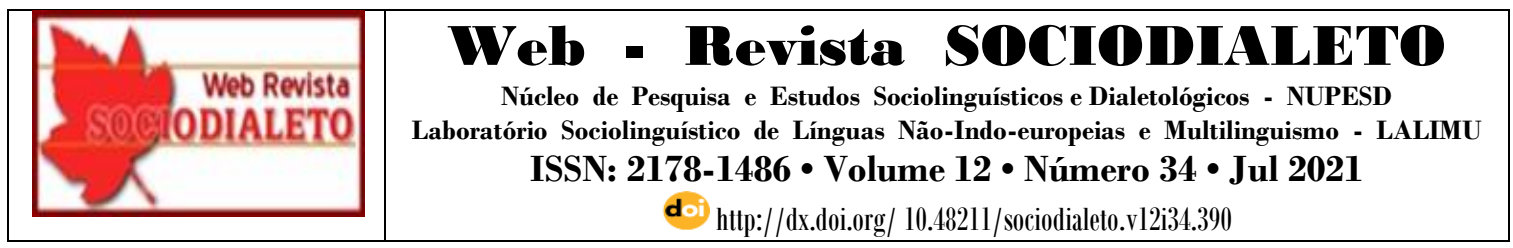

manutenção do pomerano e identificação com a cultura. Tais discursos demonstram o prestígio que a língua tem nas comunidades, muito relacionado à valorização da identidade e da cultura pomeranas (VANDRESEN; CORRÊA, 2008; MUJICA, 2013; MACKEDANZ, 2016; VAHL, 2017; BERWALDT; THUM, 2018). Acreditamos que esse prestígio deva ser valorizado para a promoção de políticas linguísticas pela manutenção do pomerano nas comunidades.

\subsection{Estudos com enfoque em ensino e aprendizagem de pomerano}

O emprego da língua pomerana nas comunidades ocorre, mais frequentemente, de maneira não institucionalizada, relegado ao lado de fora dos muros da escola. Como vimos na seção anterior, são poucos os relatos de uso do pomerano nas escolas da região da Serra dos Tapes. Isso ocorre, majoritariamente, devido a duas dificuldades: em primeiro lugar, há um problema político, que se nota na visão de que a língua falada no Brasil é o português, sendo o espaço da escola a ele destinado; em segundo lugar, há um problema operacional, motivado pelo fato de o pomerano falado no Brasil ser uma língua que necessita de planejamento de ações de revitalização linguística nos níveis do corpus, do status e da aquisição (AMARAL, 2020) para ser trabalhada nas escolas. Nesse contexto, autores como Neuenfeldt (2016) e Kuhn (2014) discutem a questão do ensino e da aprendizagem de pomerano.

O objetivo de Neuenfeldt (2016) foi desenvolver um trabalho de educação patrimonial que valorizasse a cultura local, preservando a memória e a história correspondentes à cultura pomerana. A escola onde o projeto se desenvolveu foi a mesma da pesquisa de Mujica (2013), Mackedanz (2016) e Vahl (2017). Posteriormente, o trabalho foi ampliado, sendo criado o projeto Pomervida. Tal projeto começou a ser desenvolvido em 2008 com alunos da pré-escola até o $9^{\circ}$ ano, tendo como foco rodas de diálogo abrangendo a comunidade escolar e local, propondo discussões sobre a vida do campo, a língua e o modo de viver. A cada entrevista, descobriram-se histórias silenciadas no mundo pomerano. A proposta teve como objetivo reunir informações e atividades 


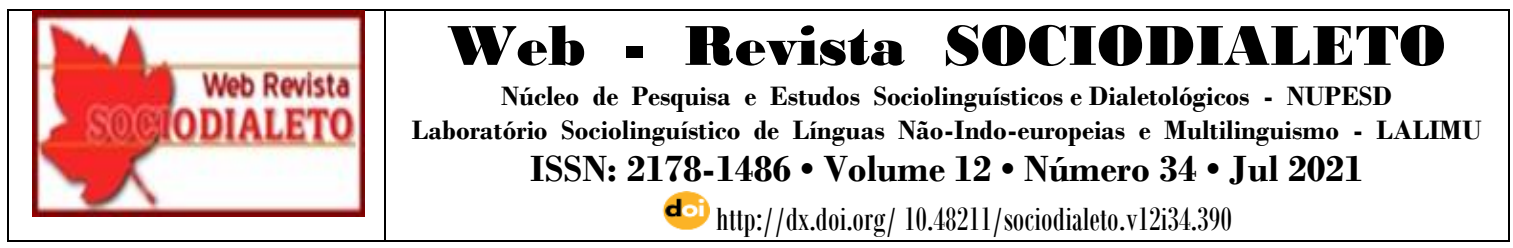

escolares e organizá-las em um acervo, por meio de trabalhos encaminhados pelos professores de várias áreas. Em 2014, o projeto abordou a escrita do pomerano com seus integrantes, pois a falta de material escrito e didático bem como de professores habituados à língua eram desafios para a inserção do pomerano na escola. No ano de 2015, o projeto contemplou atividades envolvendo teatro, poesia, música, exposição de trabalhos e registro da memória e história escritos em pomerano. Por meio do projeto, foi possível que as crianças se interessassem pela língua, pois toda a escola mobilizou-se no projeto.

Com relação ao trabalho de Kuhn (2014), seu objetivo foi descrever o desenvolvimento de sua pesquisa acerca da língua pomerana, por meio do Projeto Pomerando, na escola Germano Hübner, em Santa Tereza, São Lourenço do Sul. No projeto, o autor propôs padronizar de forma simplificada a escrita pomerana usada na comunidade e registrar vocabulário e análises gramaticais. No projeto, foram coletadas histórias, canções e brincadeiras tradicionais pomeranas, além de descritos jogos, canções de ninar, festas comunais, costumes etc. As atividades contaram com a participação de alunos de $6^{\circ}$ a $9^{\circ}$ ano e de seus familiares. Como o foco do trabalho contemplava as canções, o autor coletou, transcreveu e analisou canções pomeranas, como De mútua éna hóchtich, uma polca, e De Fest, uma valsa, ambas revelando aspectos históricos e culturais. A manutenção e documentação de artefatos culturais está de acordo com a intenção de propor ações de manutenção e documentação da língua.

Outro projeto, que ainda não está reportado em textos acadêmicos, mas sim em jornalísticos (SCHWARTZ, 2020), está sendo conduzido pela professora Tanise Stumpf em Canguçu. Tivemos a oportunidade de conversar com a professora, que nos relatou que o projeto foi uma demanda da própria comunidade escolar. As aulas são oferecidas a turmas de $6^{\circ}$ a $9^{\circ}$ ano, nas quais as crianças aprendem a escrever a sua língua materna, conforme as regras preestabelecidas (TRESSMANN, 2008), e participam de práticas culturais - dança, culinária e artesanato. Segundo a professora, os estudantes se engajam com motivação no projeto e se identificam com as práticas.

A partir desses projetos, conclui-se que o pomerano, sendo uma língua com escrita ainda não plenamente institucionalizada na região, incorpora principalmente na oralidade 


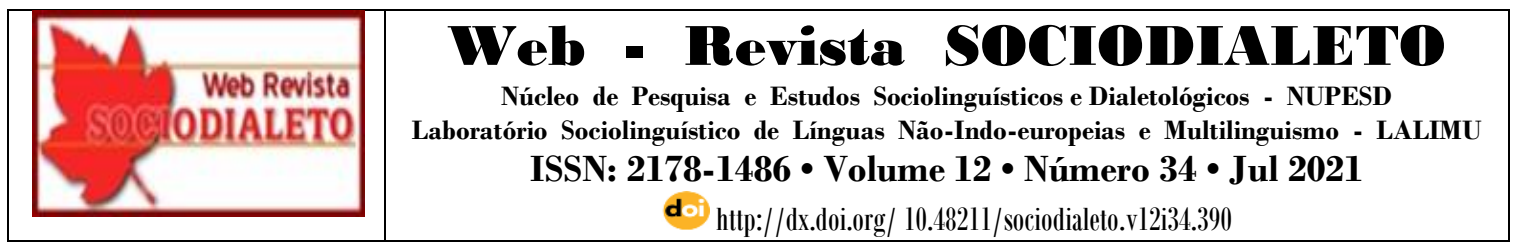

a função de contribuir para a sua manutenção. O papel da escola, como relatado nos textos sobre os projetos, é principalmente conscientizar os alunos da importância da língua da comunidade, promover e aceitar o uso da língua oral e instrumentalizar os falantes para que possam escrever a sua língua materna. A escrita, sendo introduzida em ações de ensino como as relatadas nesta subseção, pode contribuir para a manutenção da língua e para que as novas gerações se interessem mais pelo pomerano e aumentar os domínios da língua. Por isso, julgamos ser muito importante registrar e ensinar os elementos linguísticos e culturais nas escolas e nas comunidades de adultos, promovendo, por exemplo, oficinas de escrita. Além disso, sugerimos promover ações de conscientização linguística, isto é, a promoção do conhecimento explícito sobre línguas e da percepção consciente e sensível na aprendizagem, no ensino e no uso das línguas (GARCÍA, 2008). Outra ação relacionada ao ensino é democratizar o acesso ao conhecimento, também por meio das redes sociais ${ }^{12}$. É necessário realizar mais ações nas comunidades gaúchas, onde não há tanto projetos de revitalização do pomerano quanto no ES (TRESSMANN, 2008; KÜSTER, 2015; FOERSTE; BORN; DETTMANN, 2019).

\subsection{Estudos com enfoque na fonética/fonologia}

Uma discussão recorrente nos trabalhos que investigam o pomerano falado no RS diz respeito à influência da língua de imigração em aspectos fonético/fonológicos do português. Um dos autores que propõem tal discussão é Bilharva da Silva $(2015,2019)$. Em Bilharva da Silva (2015), o autor avalia a influência do pomerano na fala, escrita e percepção dos segmentos róticos de 68 estudantes dos $2^{\circ}, 3^{\circ}, 4^{\circ}$ e $6^{\circ}$ anos de duas escolas públicas, uma situada no município de Arroio do Padre e uma situada no município de Pelotas - a qual constitui o grupo controle. Dado que estudos anteriores identificaram variação na produção dos segmentos róticos em posição inicial de sílaba no português

12 Publicamos, por exemplo, postagens sobre o pomerano e assuntos afins no Instagram @ tesourolinguistico_ufpel:

https://www.instagram.com/p/CO121BaDshb/

https://www.instagram.com/p/CGjAjeRD_nN/

Acesso em: 14 maio 2020. 


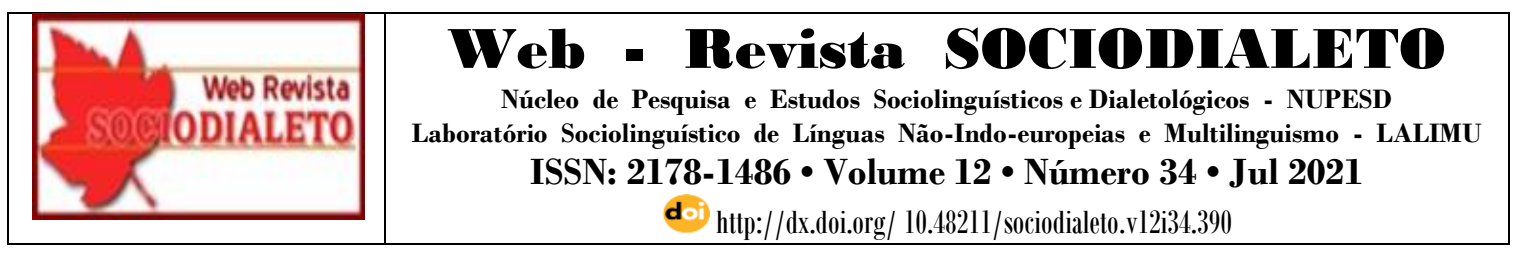

falado em comunidades germânicas no RS (MONARETTO, 2014), o estudo teve como objetivo avaliar se tal variação na fala dos pomeranos materializava-se na escrita, refletindo um maior número de erros ortográficos na grafia do dígrafo 'rr', e na percepção, resultando em maior dificuldade ao contrastar pares mínimos envolvendo segmentos róticos anteriores e posteriores. Os resultados indicaram que a produção de tepe em produções como [r]ato não constitui um fenômeno generalizado nas produções de fala das crianças de Arroio do Padre, mas uma exceção à tendência de produção da fricativa velar, como em [x]ato, variante igualmente verificada, de forma quase categórica, na fala dos pelotenses. Nos dados de percepção, monolíngues de Arroio do Padre das séries finais cometeram menos erros na distinção de pares mínimos envolvendo tepes e fricativas velares do que os estudantes das séries iniciais, enquanto os bilíngues apresentaram tais erros ao longo de todas as séries. Por fim, os resultados da escrita revelaram que a grafia dos dígrafos impõe dificuldade mesmo para os estudantes sem influência do pomerano, já que o número de erros ortográficos foi considerável para os três grupos. A diferença entre eles reside no fato de que os monolíngues de Arroio do Padre pareceram tomar consciência dessa dificuldade ao longo do desenvolvimento escolar, reduzindo consideravelmente o número de erros nas séries finais. O estudo de Bilharva da Silva (2015) contribui para uma compreensão das peculiaridades que envolvem o desenvolvimento escolar de alunos residentes de comunidades de colonização pomerana no RS, ainda que direcionando seu foco de investigação para um aspecto específico do sistema fonético/fonológico dos róticos do português.

Por sua vez, em Bilharva da Silva (2019), o autor investiga a influência do pomerano na organização temporal das sequências consonantais $[\mathrm{CR}]$ e $[\mathrm{RC}]$ - como em prato e carta - do português falado no município de São Lourenço do Sul. Para tanto, analisa se falantes bilíngues produzem vogais suarabácticas - fragmentos vocálicos de curta duração presentes em grupos consonantais, como em [ $\mathrm{p}^{\mathrm{a}}$ rato] - distintas daquelas produzidas por falantes monolíngues, tomando como pressuposto teórico a Fonologia Gestual (BROWMAN; GOLDSTEIN, 1986; STERIADE, 1990). Foram investigadas as produções de dez participantes mulheres, com idades acima de 42 anos, divididas em dois grupos: bilíngues, composto por cinco participantes que têm o pomerano como língua 


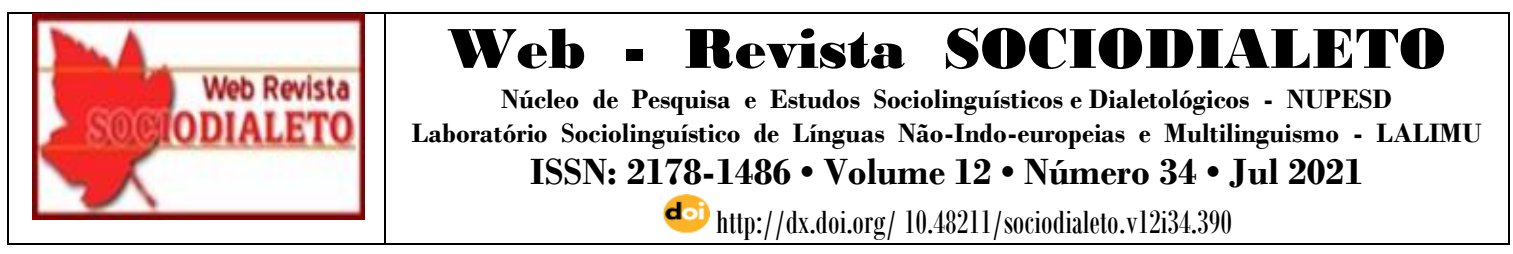

dominante; e monolíngues, composto por cinco participantes residentes na zona urbana do município de Pelotas, que não utilizam em seu cotidiano outra língua além do português. As produções realizadas foram obtidas a partir de três experimentos de coleta, os quais perpassavam diferentes níveis de controle e estilo. Os resultados do estudo revelaram a presença elevada de vogais suarabácticas nas produções dos dois grupos, embora as bilíngues tenham apresentado índice significativamente inferior desses elementos vocálicos. Na produção das bilíngues, além disso, foram verificadas vogais suarabácticas mais longas, o que pode indicar uma coordenação gestual mais lenta entre os gestos articulatórios da sequência consonantal, possivelmente motivada pela presença do pomerano. Além disso, as participantes bilíngues produziram número significativamente menor de tepes em posição pós-vocálica, empregando, nessa posição, variantes róticas como vibrantes múltiplas, fricativas palato-alveolar desvozeadas e aproximantes alveolares, o que igualmente pode revelar um papel do pomerano, que não apresenta tepes em posição final de sílaba. O estudo de Bilharva da Silva (2019) demonstra que o contato entre as duas línguas parece gerar reorganizações temporais na fala dos indivíduos bilíngues, motivadas pela presença, na gramática das línguas, de elementos fonéticos não contrastivos. Dessa forma, a pesquisa arrola argumentos para a incorporação de elementos fonéticos aos modelos fonológicos, auxiliando a repensar a relação entre esses dois domínios, Fonética e Fonologia.

A pesquisa de Kuhn (2011) teve por objetivo investigar a influência que o pomerano e o português exercem na aprendizagem da fonética do inglês. $\mathrm{O}$ foco foi a percepção das vogais /i/, /I/, /E/, /æ/, /u/, /ひ/, específicas do inglês, bem como o efeito da L1 e da L2 no processamento grafo-fônico-fonológico do inglês como L3. Para isso, foi realizado primeiramente um teste de percepção das vogais do inglês e, após, um estudo de priming fonético-fonológico e ortográfico. O estudo foi realizado com aprendizes de inglês em dois ambientes: o primeiro foi na Escola Municipal Francisco Frömming, no interior de São Lourenço do Sul, cujos participantes estavam no $7^{\circ}$ e $8^{\circ}$ anos, divididos em falantes monolíngues do português e falantes bilíngues (pomerano e português); o segundo ambiente foi um curso de inglês situado na cidade de Pelotas, cujos alunos do nível básico constituíram o grupo controle. Esses alunos, segundo a autora, "afirmaram 


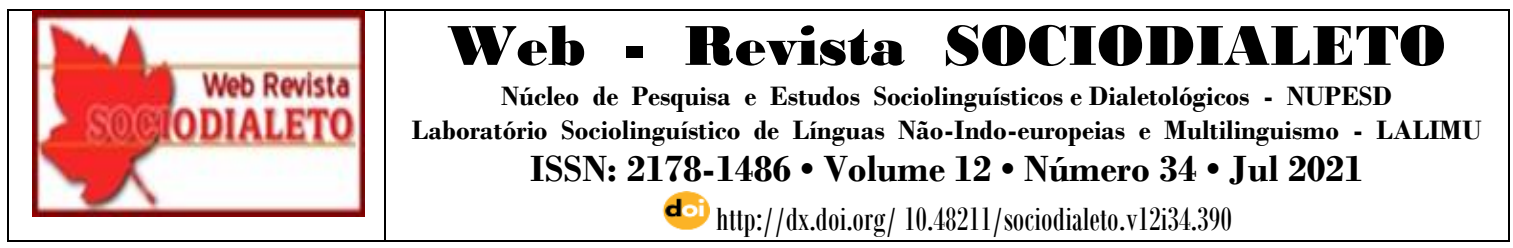

não ter nenhum tipo de contato com falantes bilíngues do PB-pomerano" (KUHN, 2011, p. 38). Os resultados mostraram que tanto os bilíngues quanto os monolíngues tiveram uma porcentagem baixa de acurácia na percepção das vogais /I/ e /æ/, visto que essas não pertencem nem ao português nem ao pomerano. Quanto à vogal /ð/, apesar da hipótese de que os bilíngues teriam resultados mais favoráveis em sua percepção por essa estar presente no pomerano, os dois grupos - monolíngues e bilíngues de São Lourenço do Sul - tiveram baixa porcentagem de acerto. Com relação às demais vogais, /i/, / / / e /u/, a expectativa era de que não haveria diferenças significativas, já que essas pertencem tanto ao português quanto ao pomerano. No entanto, segundo a autora, "isso não ocorreu, pois mesmo as vogais presentes nos inventários vocálicos da L1 tiveram uma porcentagem de identificação baixa, pois foram frequentemente confundidas com outras vogais" (KUHN, 2011, p. 60). Uma possível explicação para esses resultados é o fato de que os monolíngues de São Lourenço do Sul estão expostos ao sotaque dos bilíngues, o que pode colaborar para esses efeitos. O estudo de Kuhn (2011) relacionou pomerano com inglês e português, abordando a influência do pomerano na percepção de línguas de prestígio.

Blank (2013) teve por objetivo descrever e analisar as possíveis influências fonológicas na produção escrita do português por crianças bilíngues de pomerano/português, especialmente no que se refere à troca de fonema surdo por sonoro, à troca do ' $r$ ' forte (em contexto de rr e início de sílaba em português) pelo ' $r$ ' fraco e à troca do ditongo nasal 'am' por 'on'. Foram coletadas oito produções textuais mensalmente, o que caracterizou a pesquisa como longitudinal. Além disso, foram recolhidos dados de produção de fala dos informantes, alunos de $2^{\circ}, 3^{\circ}$ e $4^{\circ}$ ano de uma escola de Arroio do Padre. Os resultados mostram que houve majoritariamente troca de obstruintes surdo-sonoras, embora a grande maioria das ocorrências registradas não tivessem, de acordo com a autora, influência do pomerano, diferentemente do previsto por estudos anteriores. A análise qualitativa também não demonstrou grande influência do pomerano na escrita do português dos bilíngues. Entretanto, a análise do corpus mostrou que houve influência da língua materna na grafia dos róticos, pois os dados dos bilíngues revelaram índice relativamente alto, em comparação com dados de monolíngues, da substituição gráfica do ' $r$ ' forte pelo ' $r$ ' fraco, totalizando $80 \%$ de trocas. 


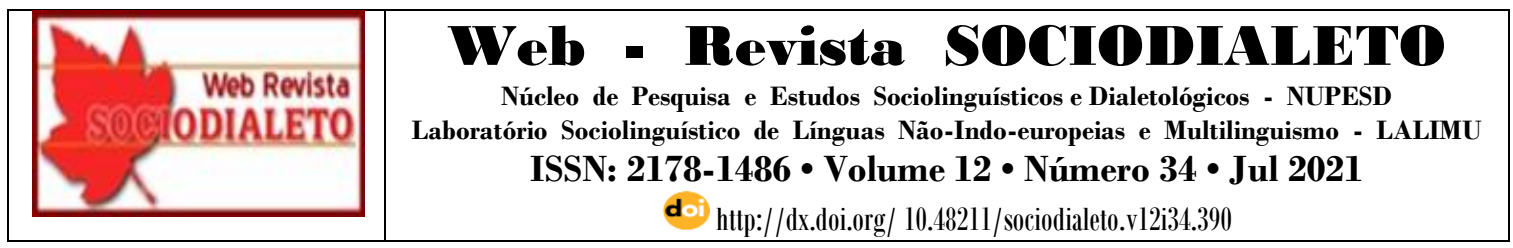

$\mathrm{Na}$ troca do ditongo nasal 'am' por 'on', foi registrado um índice de $41 \%$ de erros envolvendo tal fenômeno; assim, esse dado foi condizente com a ideia de influência do pomerano na produção escrita em português. Nos dados de fala, a análise acústica mostrou a influência do pomerano na pronúncia das oclusivas sonoras, as quais mostraram Voice onset time (VOT) condizentes com o sistema pomerano. Essas influências diminuíram na comparação entre as turmas. A pesquisa se mostra relevante por demonstrar aspectos do processo de aquisição da escrita por crianças bilíngues que não têm o português como língua materna, pois apresentou resultados que parecem específicos à comunidade investigada, o que motiva o desenvolvimento de estratégias de ensino voltadas a essas especificidades.

O objetivo do estudo de Santos (2017) foi analisar a consciência fonoarticulatória na aquisição da modalidade escrita da linguagem de falantes monolíngues de português e bilíngues de pomerano/português. Além disso, buscou-se relacionar os níveis dessa consciência com o domínio da escrita na relação som/grafema. A pesquisa foi realizada em uma escola pública de Arroio do Padre e dividiu-se em quatro etapas. A primeira consistiu na análise das coletas de escrita e de fala de crianças dos $2^{\circ}, 3^{\circ}$ e $4^{\circ}$ anos dessa escola apurados por Bilharva da Silva (2015), sendo elas 10 bilíngues e 12 monolíngues. A segunda etapa consistiu na aplicação de testes de nomeação de gravuras a partir da leitura labial de palavras no português em comparação a surdos. Para a terceira etapa, a autora também contou com a participação de alunos de $2^{\circ}, 3^{\circ}$ e $4^{\circ}$ anos para analisar a consciência, selecionando 10 sujeitos bilíngues e 07 monolíngues. Por fim, a quarta etapa baseou-se na metodologia de Bilharva da Silva (2015) e contou com a contribuição os mesmos participantes da etapa anterior. O objetivo era analisar como as crianças bilíngues operam os sons dos róticos e das obstruintes que são diferentes da língua padrão. Os resultados mostraram que, na primeira etapa, bilíngues e monolíngues obtiveram alterações na produção dos sons obstruintes. De acordo com a autora, essas trocas, para os bilíngues, poderiam estar relacionadas às transferências grafo-fônico-fonológicas. Na segunda etapa, os participantes surdos oralizados apresentaram mais erros que acertos nas atividades de leitura labial, o que pode indicar que o vozeamento pode ser pouco visível em pistas labiais e/ou faciais. Em relação à terceira etapa, os bilíngues e monolíngues 


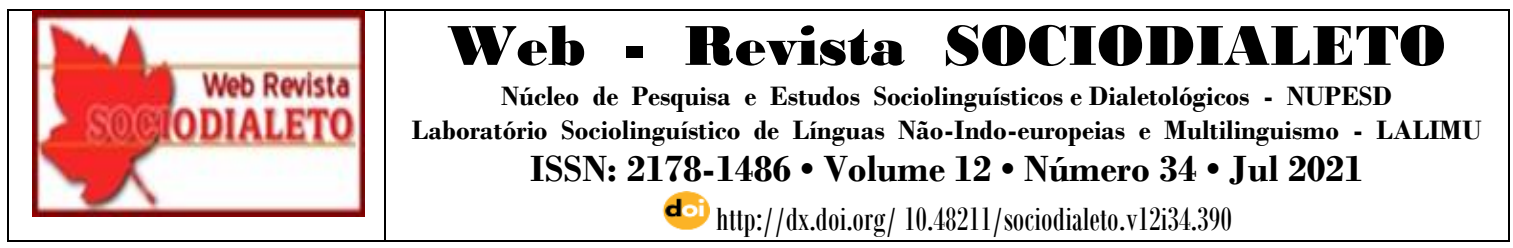

obtiveram baixo desempenho nas tarefas de consciência. De acordo com a autora, a dificuldade dos bilíngues pode ser resultado do baixo uso de subvocalizações e das limitações do instrumento para a identificação dos segmentos bilabiais. Já na quarta etapa, foi possível observar que ocorreram alterações quanto à sonoridade e ao emprego dos róticos pelos bilíngues. A respeito da escrita, apesar de os dois grupos terem cometido trocas na grafia dos róticos e obstruintes, os bilíngues efetuaram mais trocas entre os " $\mathrm{r}$ " e menos erros em relação à oposição surdo/sonoro. A pesquisa de Santos possibilita uma análise mais crítica a respeito das variedades faladas por indivíduos bilíngues, bem como dos reflexos dessas variedades na modalidade escrita. $\mathrm{O}$ menor número de erros ortográficos cometidos por bilíngues quanto aos pares vozeados/desvozeados, por exemplo, vai de encontro a suposições iniciais de que esses participantes cometeriam mais erros, motivados pelas trocas entre esses segmentos que realizam na fala. Assim, o que se nota não é uma transposição direta da fala na escrita, ou seja, os bilíngues são constantemente despertados para os erros envolvendo pares vozeados/desvozeados, tornando-se mais efetivos, até mesmo que os monolíngues, na grafia desses pares.

Os estudos fonético-fonológicos podem ser divididos em dois grupos temáticos. O primeiro grupo contempla estudos sobre a influência da língua de imigração na percepção e na produção de português (BLANK, 2013; BILHARVA DA SILVA, 2019) e inglês (KUHN, 2011). Os estudos mostram influências do pomerano na produção das oclusivas do português, na organização temporal na produção de encontros consonantais do português e na percepção de vogais inglês, respectivamente. Estudos sobre influências translinguísticas podem demonstrar benefícios do conhecimento de uma língua de imigração, demonstrando uma relevância cognitiva que se revela, por exemplo, na aprendizagem de outras línguas, como o inglês. O segundo grupo inclui estudos sobre a relação entre fonologia e escrita (BLANK, 2013; BILHARVA DA SILVA, 2015; SANTOS, 2017). Tais estudos mostram especificidades que concernem ao desenvolvimento da escrita de alunos falantes de pomerano, contribuindo para o aprimoramento de métodos de ensino com relação, por exemplo, aos róticos e aos ditongos nasais. Além disso, os estudos mostram que alguns "erros" não são 


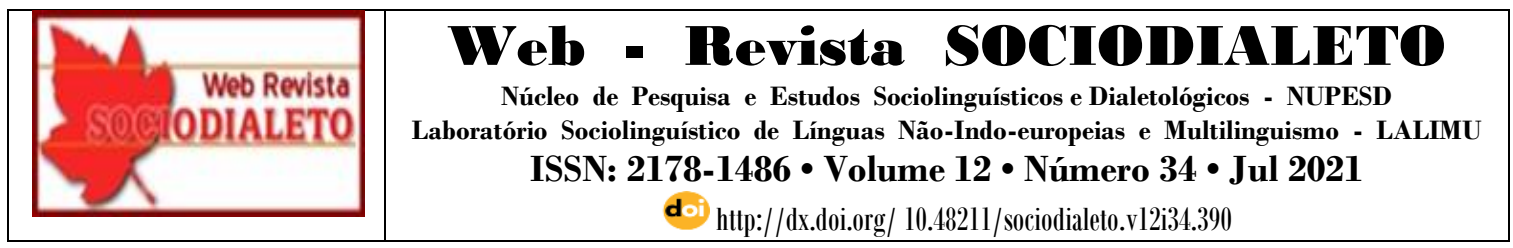

necessariamente influência do pomerano, mas fazem parte do processo de aquisição da escrita inclusive de crianças monolíngues falantes de português.

\subsection{Estudos com enfoque na psicolinguística}

Estudos vinculados à última categoria têm como objetivo, de forma geral, investigar o processamento das línguas, considerando diferentes níveis linguísticos e diferentes populações - por exemplo, bilíngues, disléxicos, afásicos. Para dar conta do processamento, é necessário relacionar aspectos linguísticos com cognitivos, como funções executivas, memória e criatividade. Encontramos três estudos que podem ser inseridos nessa perspectiva (BANDEIRA, 2010, 2014; SCHRAMM, 2015).

O estudo de Bandeira (2010) teve como objetivo investigar diferenças no desempenho de crianças multilíngues - falantes de pomerano e português e aprendizes de inglês - e de crianças monolíngues na produção de plosivas surdas nas três línguas e em tarefas de funções executivas. Portanto, o estudo também investigou o processamento fonológico. As crianças tinham de 8 a 10 anos e foram recrutadas em Arroio do Padre. Para investigar a produção, a autora aplicou um instrumento de contação de histórias nas três línguas, acompanhado de um jogo que incentivava a produção de palavras-alvo iniciadas pelas consoantes plosivas surdas $/ \mathrm{p} / \mathrm{/} / \mathrm{t} / \mathrm{e} / \mathrm{k} /$. Para a análise, a autora utilizou VOT e comparou as médias dos dois grupos. Os resultados mostraram diferenças entre os grupos na produção das plosivas do inglês, apontando para influência do pomerano na produção das plosivas aspiradas do inglês e nas plosivas do português. O estudo investigou também o efeito do multilinguismo nas funções executivas por meio das Simon (não verbal) e Stroop (verbal). Para conseguir realizar esses testes com sucesso, o participante necessita ignorar a tendência de produzir a resposta mais automática. Foram aplicadas duas versões do teste Stroop: uma em português e outra em pomerano, produzida a partir de um estudo piloto com a comunidade-alvo. A hipótese defendida era a de que as crianças multilíngues teriam vantagens na tarefa, devido à habilidade inconsciente de controlar o uso de suas várias línguas no seu cotidiano. Essa habilidade 


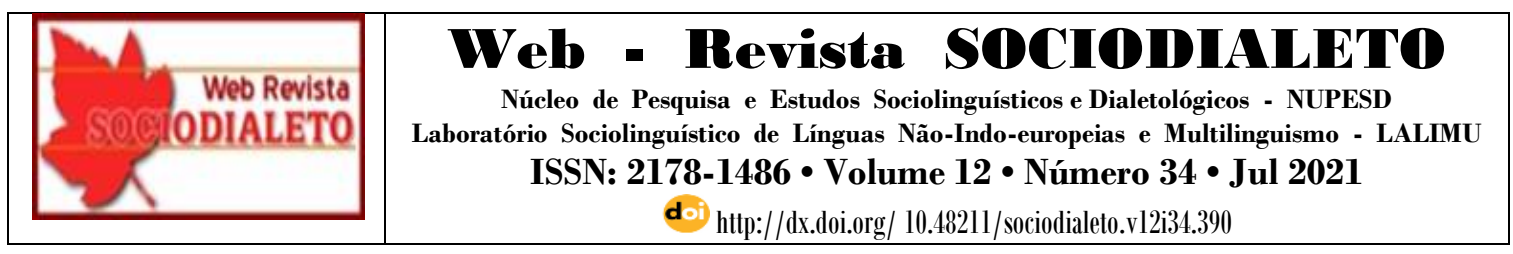

poderia auxiliá-las no momento de terem de controlar as respostas para a decisão, porque julga-se que os processos linguísticos e cognitivos estão correlacionados. No teste realizado em português, não houve diferenças significativas entre os grupos de monolíngues e multilíngues falantes de pomerano. No entanto, quando se comparou o desempenho dos participantes multilíngues na sua L1, eles tiveram vantagem nas duas variáveis analisadas. Da mesma forma, houve vantagem dos multilíngues falantes de pomerano na tarefa Simon. O estudo sugere, portanto, que o processamento de pomerano pelas crianças, mesmo na escrita, seria mais confortável e automático. Além disso, o estudo tangencia a facilidade dos falantes de pomerano na aprendizagem da língua inglesa, devido às proximidades entre as línguas, por exemplo, na aspiração das plosivas.

Na sua pesquisa subsequente, a nível de doutorado, Bandeira (2014) contatou as crianças que participaram do estudo anterior (BANDEIRA, 2010) para refazerem os experimentos de funções executivas, configurando um estudo longitudinal. Na segunda aplicação dos testes, os participantes foram mais rápidos do que na aplicação anterior, havendo diferença estatisticamente significativa somente no grupo dos monolíngues. Esses resultados podem ter relação com a influência que o pomerano exerce nos falantes na região de Arroio do Padre e Pelotas, pois em muitos casos, o bilinguismo é passivo, ou seja, a vantagem bilíngue não teria aparecido devido a características próprias do bilinguismo pomerano-português. Eventuais vantagens bilíngues apareceriam no bilinguismo ativo e seriam restritas à infância e ao envelhecimento no contexto brasileiro (LIMBERGER; BUCHWEITZ, 2012). Esse contexto que favoreceria o aparecimento de vantagens bilíngues não condiz com o avaliado no estudo. No entanto, essa questão é altamente controversa e foge ao escopo deste trabalho. Na tarefa Stroop, houve vantagem bilíngue em todas as condições, corroborando o resultado do trabalho anterior.

Com relação ao trabalho de Schramm (2015), seu objetivo foi verificar as diferenças entre bilíngues (falantes de pomerano e português) e 25 monolíngues da cidade de Pelotas em tarefas de criatividade, atenção seletiva e atenção dividida. Todos os participantes eram adultos e compunham grupos com perfis semelhantes. Para avaliar a criatividade, foi aplicado o teste psicométrico de Torrance de criatividade figural e, para avaliar a atenção, foi aplicado o teste de trilhas coloridas. Ambos os testes foram 


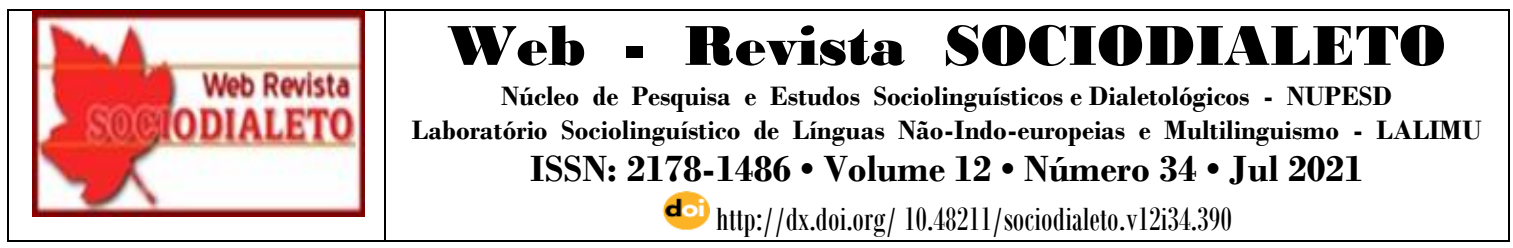

adaptados e validados para a realidade brasileira. A hipótese do trabalho, baseada em estudos estrangeiros, era de que os bilíngues teriam vantagem no desempenho cognitivo em geral, o que inclui a criatividade. Os resultados dos testes mostraram escores médios próximos nos dois grupos, cujas diferenças não foram estatisticamente significativas. Essa ausência de um efeito do bilinguismo pomerano-português na criatividade e na atenção foi explicada por meio das especificidades da população investigada, em comparação às amostras dos estudos estrangeiros: falantes de uma língua "ágrafa", contexto de aquisição e uso das línguas, status socioeconômico e nível de escolaridade inferiores, valores históricos e culturais diferentes. A autora chama a atenção à dificuldade de conduzir pesquisas com falantes de línguas que não possuem testes de proficiência e fluência, pois essa variável claramente influencia a cognição. Lança-se a hipótese de que o bilinguismo com uma língua minoritária conferiria efeitos diferentes na cognição, se comparado ao bilinguismo com línguas majoritárias.

As pesquisas psicolinguísticas contribuem para a discussão sobre os efeitos do bilinguismo com uma língua minoritária na cognição. A maior parte dos estudos conduzidos no mundo sobre esse tema investiga falantes de línguas minoritárias, de modo que a controversa discussão sobre a "vantagem bilíngue" não tem considerado especificidades desses falantes. É importante conduzir estudos com falantes de línguas minoritárias para verificar a existência da vantagem bilíngue em diferentes grupos e em diferentes aspectos da cognição.

\section{Considerações finais}

Com este trabalho, buscamos verificar o desenvolvimento das pesquisas linguísticas sobre o pomerano do RS. Os resultados da revisão revelam diferentes possibilidades de investigação sobre uma língua: desde estudos sobre aspectos linguísticos (fonológicos, lexicais e sintáticos) até estudos sobre os efeitos de usar duas ou mais línguas. A pesquisa sobre a língua é relativamente recente, pois tem acontecido nos últimos 15 anos e apresenta, ainda, inúmeras possibilidades. 


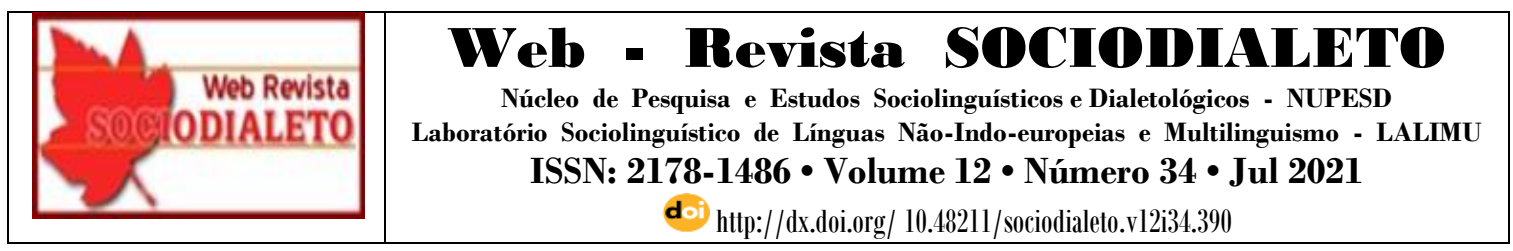

Os estudos apontam lacunas relacionadas principalmente à descrição, ao uso, à escrita e às políticas linguísticas do pomerano falado no RS. É urgente, por exemplo, investigar fatores atrelados ao uso atual do pomerano no estado e monitorar esses fatores ao longo dos próximos anos. Além disso, as lacunas sugerem investigar como as convenções de escrita propostas por Tressmann (2008), que já foram difundidas em algumas comunidades, estão sendo recebidas e utilizadas. Estudos psicolinguísticos e da linguística aplicada podem contribuir também para verificar como a leitura e a escrita estão sendo processadas e aprendidas. Ainda, estudos sobre contato linguístico nas comunidades e em situações formais de aprendizagem devem considerar outras línguas além do português, como inglês, alemão e espanhol. Na Universidade Federal de Pelotas, estão sendo conduzidos estudos para contribuir com o preenchimento dessas lacunas. Os estudos são vinculados ao Laboratório de Psicolinguística, Línguas Minoritárias e Multilinguismo (Laplimm) e abordam influências do pomerano no processamento e na aprendizagem de inglês (mestrado de Gabriela Griep), leitura em pomerano utilizando duas convenções de escrita (mestrado de Gisleia Blank) e acesso lexical em pomerano (pesquisa de iniciação científica de Elizandra Netto e Lisandro Völz).

As investigações sobre a língua devem estar relacionadas a ações de políticas linguísticas realizadas pelas comunidades e pelos governantes. Estudos sobre o pomerano e o bilinguismo/multilinguismo no qual ele está inserido são, portanto, essenciais para criar estratégias de manutenção da língua, uma preocupação pertinente para manter a sua vitalidade. É necessário conjugar esforços para o planejamento do corpus, do status e da aquisição da língua (AMARAL, 2020), o que necessita de muita pesquisa e o envolvimento de uma grande equipe. Tudo isso requer uma coordenação entre comunidade, governo e universidade.

No caso do pomerano, a importância da manutenção ressalta-se pelo fato de essa língua praticamente não mais ser falada na Europa, constituindo a peça histórica de uma nação que necessitou fugir de sua terra para preservar sua identidade cultural, da qual a língua é o traço mais importante. Assim, descrever, analisar e discutir o pomerano constitui uma contribuição também para o resgate e a valorização histórica de um povo tradicional. Além disso, a pesquisa sobre o pomerano possui uma importante contribuição 


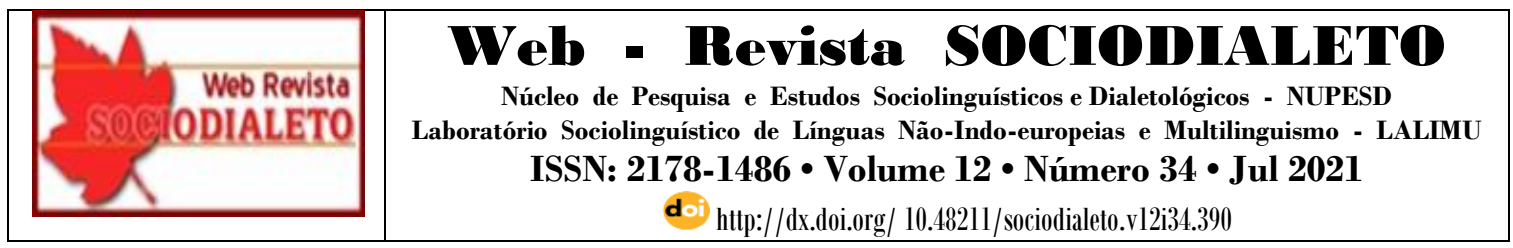

para os estudos sobre contato linguístico, ensino e aprendizagem de línguas, fonética e fonologia e psicolinguística.

Há algumas barreiras que dificultam um pouco a realização de pesquisas sobre qualquer língua minoritária, como, por exemplo, a carência de materiais escritos, o número reduzido de falantes e o acesso às comunidades. É necessário superar esses obstáculos para aumentar o número de pesquisas, de modo que as línguas minoritárias recebam a atenção que merecem. Acreditamos que o foco da linguística contemporânea, no Brasil, ainda tem sido as línguas majoritárias.

Os estudos evidenciam que as habilidades linguísticas e cognitivas dos falantes de pomerano são diferenciadas e os efeitos positivos de saber essa língua, combinados com outras vantagens culturais, socioeconômicas e linguísticas do bilinguismo/multilinguismo, podem servir como argumentos para desmistificar ideias errôneas e aumentar ainda mais o prestígio da língua dentro e fora das comunidades. Crenças e atitudes positivas podem auxiliar na promoção e na manutenção de línguas minoritárias e na perseverança na comunicação nessas línguas com as gerações vindouras, fomentando o multilinguismo.

\section{Referências}

ALTENHOFEN, Cléo Vilson. Política lingüística, mitos e concepções lingüísticas em áreas bilíngües de imigrantes (alemães) no Sul do Brasil. Revista Internacional de Linguistica Iberoamericana, v. 2, n. 1, p. 83-93, 2004.

ALTENHOFEN, Cléo Vilson. Bases para uma política linguística das línguas minoritárias no Brasil. In: NICOLAIDES, Christine et al. (orgs.). Política e Políticas Linguísticas. Campinas: Pontes Editores, 2013. p. 93-116.

AMARAL, Luiz. Strategies for endangered language revitalization and the Brazilian reality. Cadernos de Linguística, v. 1, n. 3, p. 01-44, 2020. https://doi.org/10.25189/2675-4916.2020.v1.n3.id251

BANDEIRA, Marta Helena Tessmann. Diferenças entre crianças monolíngues e multilíngues no desempenho de tarefas de funções executivas e na transferência de padrões de VOT (Voice Onset Time) entre as plosivas surdas do pomerano, do português e do inglês. 2010. 93 f. Dissertação (Mestrado em Letras) - Universidade Católica de Pelotas, Pelotas, 2010. 


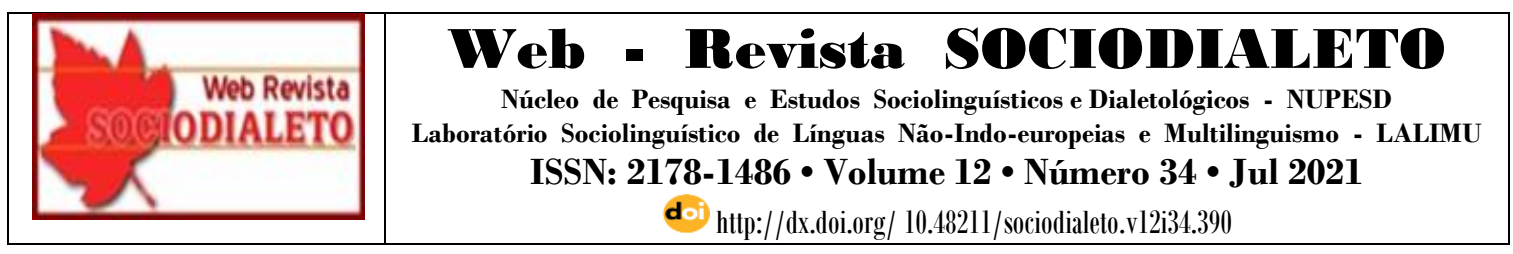

BANDEIRA, Marta Helena Tessmann. Vantagens Bilíngues. Um Estudo Sobre as Diferenças nas Funções Executivas - Controle Inibitório e Atenção - Entre Monolíngues e Bilíngues. 2014. 168 f. Tese (Doutorado em Letras) - Universidade Católica de Pelotas, Pelotas, 2014.

BEILKE, Neubiana Silva Veloso. Pommersche Korpora: uma proposta metodológica para compilação de corpora dialetais. 2016. 285 f. Dissertação (Mestrado em Estudos Linguísticos). Universidade Federal de Uberlândia, Uberlândia, 2016.

BERWALDT, Myrna Gowert; THUM, Carmo. Territorialidades da língua pomerana: cultura, identidade e mundo escolar. Revista Gepes Vida, v. 4, n. 8, p. 1-14, 2018.

BILHARVA DA SILVA, Felipe. Produção oral e escrita dos róticos em Arroio do Padre (RS): avaliando a relação português/pomerano com base na Fonologia Gestual. 2015. 246 f. Dissertação (Mestrado) - Programa de Pós-Graduação em Letras, Centro de Letras e Comunicação, Universidade Federal de Pelotas, Pelotas, 2015.

BILHARVA DA SILVA, Felipe. O contato português-pomerano na produção dos grupos [Cr] e [rC]: o caso das vogais suarabácticas. 2019. $280 \mathrm{f}$. Tese (Doutorado em Letras). Programa de Pós-Graduação em Letras, Pontifícia Universidade Católica do Rio Grande do Sul, Porto Alegre, 2019.

BLANK, Marceli Tessmer. Influências fonológicas na aquisição da escrita do português por crianças bilíngues (pomerano/português brasileiro). Dissertação (Mestrado) - Programa de Pós-Graduação em Educação, Faculdade de Educação, Universidade Federal de Pelotas.

BROWMAN, Catherine; GOLDSTEIN, Louis. Towards an articulatory phonology. $\begin{array}{llllll}\text { Phonology Yearbook, } & \text { v. } & 3, & \text { p. } & 219-252, & \end{array}$ https://doi.org/10.1017/S0952675700000658

COLEGIADO da Diversidade Linguística do Rio Grande do Sul. Diversidade linguística do RS: inventariar, reconhecer, salvaguardar, promover. Conselho Estadual de Cultura do RS. Documento. Porto Alegre, 2018. Disponível em: https://www.ufrgs.br/projalma/documento-sobre-a-diversidade-linguistica/. Acesso em: 14 maio 2021.

EBERHARD, David; SIMONS, Gabriela; FANNING, Charles. Ethnologue: Languages of the World. Twenty-third edition. Dallas, Texas: SIL International, 2021. Disponível em: http://www.ethnologue.com. Acesso em: 18 mar. 2021.

FOERSTE, Erineu; BORN, Joachim; DETTMANN, Jandira Marquardt. Língua pomerana na escola: práticas docentes e diversidade linguística Revista Brasileira de Educação, v. 24, e240011, 2019. https://doi.org/10.1590/s1413-24782019240011

GARCÍA, O. Multilingual Language Awareness and Teacher Education. Encyclopedia of language and education. Knowledge about language, v. 6, p. 385-400, 2008. https://doi.org/10.1007/978-0-387-30424-3_163

GROSJEAN, François. Bilingual: life and reality. Cambridge e Londres: Harvard University, 2010. https://doi.org/10.4159/9780674056459 


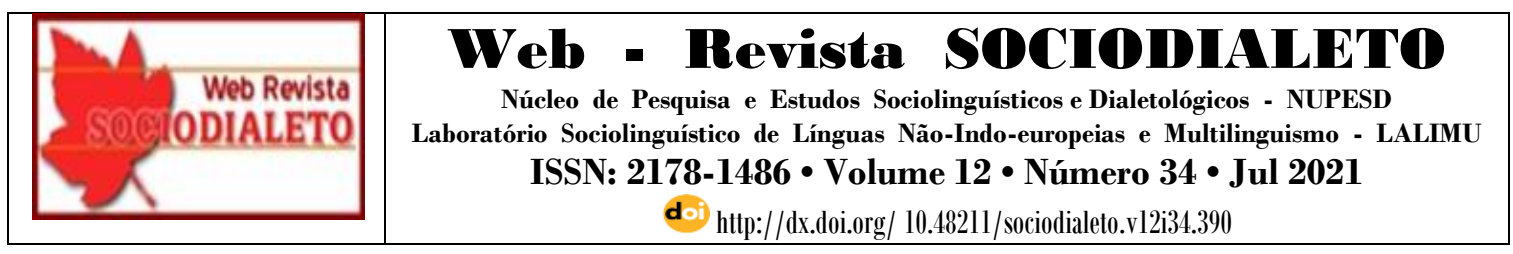

IPOL. Lista de línguas cooficiais em municípios brasileiros, 2020. Instituto de Investigação e Desenvolvimento em Política Linguística. Disponível em: http://ipol.org.br/lista-de-linguas-cooficiais-em-municipios-brasileiros/. Acesso em: 12 set. 2020.

KAUFMANN, Göz. Sorvete und Tema is nich Dütsch: Zur lexikalischen Integration von Entlehnungen in drei deutschen Varietäten Südbrasiliens. In: ELLER-WILDFEUER, Nicole; MAITZ, Peter; WILDFEUER, Alfred. (Eds.). Sprachkontaktforschung explanativ. Stuttgart: Steiner, 2017. p. 260-307.

KAUFMANN, Göz et al. Minority groups and language diversity in Germany and Brazil: an interview with Göz Kaufmann. Caderno de Letras, v. 35, p. 279-293, 2019. https://doi.org/10.15210/cdl.v0i35.17784

KAUFMANN, Göz; DURAN, Daniel. Of snoidels and hofdüütsch: Some (Standard German) keys to the phonetic variation in Pomerano. In: GANSWINDT, Brigitte; HETTLER, Yvonne; SCHRÖDER, Ingrid. Niederdeutsche Dialektologie (ZDL-special topic). Stuttgart: Steiner. No prelo.

KUHN, Danilo. Projeto Pomerano: Mais Cultura (pomerana) nas Escolas. In: Anais do $2^{\circ}$ Encontro da ASPHE. Porto Alegre: Universidade Federal do Rio Grande do Sul, 2014, p. 1-15.

KUHN, Paula Cristiane. A percepção de vogais do inglês por falantes monolíngues (português) e bilíngues (pomerano/português) e o papel do bilinguismo no processamento grafo-fônico-fonológico da L3. 2011. 92 f. Dissertação (Programa de Pós-Graduação em Letras) - Universidade Católica de Pelotas, Pelotas.

KÜSTER, Sintia B. Cultura e língua pomeranas: um estudo de caso em uma escola do ensino fundamental no município de Santa Maria de Jetibá - Espírito Santo - Brasil. 2015. Dissertação (Mestrado). Universidade Federal do Espírito Santo, Vitória, 2015.

LIMBERGER, Bernardo; BUCHWEITZ, Augusto. Estudos sobre a relação entre bilinguismo e cognição: o controle inibitório e a memória de trabalho. Letrônica, v. 5, n. 3, p. 67-87, 2012.

MACKEDANZ, Daiane. O papel da identidade para a manutenção do Pomerano na Serra dos Tapes. 2016. 181 f. Dissertação (Mestrado) - Programa de Pós-Graduação em Letras, Centro de Letras e Comunicação, Universidade Federal de Pelotas, Pelotas, 2016.

MACKEY, William. The Description of Bilingualism. In: WEI, Li. The Bilingualism Reader. London: Routledge, 2000. p. 26-54.

MILESKI, Ivanete. Variação no Português de contato com o Polonês no Rio Grande do Sul: vogais médias tônicas e pretônicas. 2017. Tese (Doutorado em Letras). Programa de Pós-Graduação em Letras, Pontifícia Universidade Católica do Rio Grande do Sul, Porto Alegre, 2017.

MONARETTO, Valéria. Realizações de R. In: BISOL, Leda; BATTISTI, Elisa (orgs.) O português falado no sul do Brasil. Porto Alegre: EDIPUCRS, 2014. p. 121-132. 


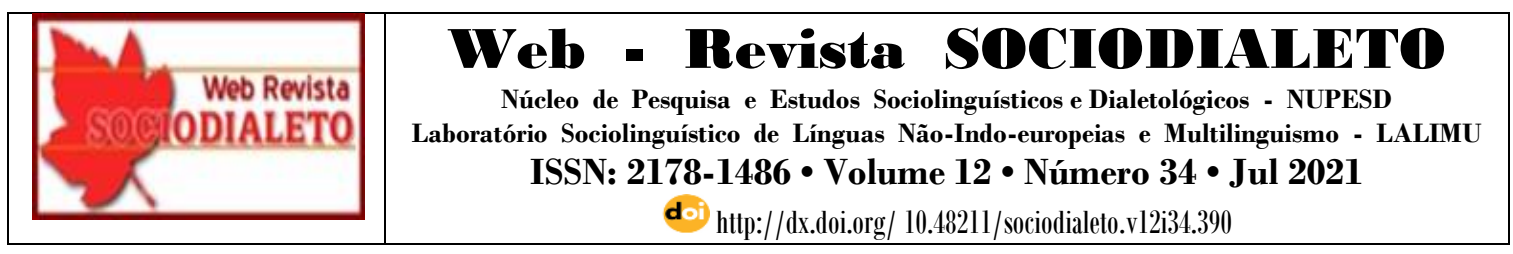

MORENO, Mario Ruiz; GABRIEL, Christoph (2020). Voice Onset Time in PomeranoBrazilian Portuguese bilinguals. In: GABRIEL, Christoph; PEŠKOVÁ, Andrea; SELIG, Meisenburg (eds.). Contact, variation and change. Studies in honor of Trudel Meisenburg. Berlin: Erich Schmidt, 2020. p. 57-77.

MOZZILLO, Isabella; SPINASSÉ, Karen Pupp. Políticas linguísticas familiares em contexto de línguas minoritárias. Linguagem \& Ensino, v. 23, n. 4, p. 1297-1316, 2020. https://doi.org/10.15210/rle.v23i4.18521

MUJICA, Marina. Atitude, orientação e identidade linguística dos pomeranos residentes na comunidade de Santa Augusta - São Lourenço do Sul, RS. 2013. 101 f. Dissertação (Mestrado em Letras) - Universidade Federal de Pelotas, Pelotas, 2013.

NEUENFELDT, Cristiane Siefert. Língua pomerana: da oralidade para a escrita Trajetória da Escola Municipal de Ensino Fundamental Martinho Lutero. XIII Encontro Nacional da História Oral, Porto Alegre: Universidade Federal do Rio Grande do Sul, p. 1-11, 2016.

POSTMA, Gertjan. Complex complementizers and the structural relation with weak T". New (morpho)syntactic data from a Pomeranian language island in Brazil. Language Typology and Universals, v. 67, n. 4, p. 627-663, 2014. https://doi.org/10.1515/stuf$\underline{\text { 2014-0032 }}$

RIO GRANDE DO SUL. Lei No 15.459, de 26 de março de 2020. Disponível em: http://www.al.rs.gov.br/legis/M010/M0100018.asp?Hid_IdNorma=66200\&Texto=\&Ori gem $=1$. Acesso em: 14 maio 2021.

ROSENBERG, Peter. The Impact of Variation, Contact, and Change on Case Morphology: What Can We Learn from Language Islands in the 'Flood'? Variationist Linguistics meets Contact Linguistics. Vienna: Vienna University Press, 2020. p. 5192. https://doi.org/10.14220/9783737011440.51

SALAMONI, Giancarla; WASKIEVICZ, Carla Aparecida. Serra dos Tapes: espaço, sociedade, natureza. Tessituras, v. 1, n. 1, p. 73-100, 2013.

SANTOS, Paola. O papel da Consciência Fonoarticulatória na aquisição da escrita de falantes monolíngues e bilíngues (pomerano/português): dados de Arroio do Padre. 2017. 222 f. Dissertação (Mestrado) - Programa de Pós-Graduação em Letras, Centro de Letras e Comunicação, Universidade Federal de Pelotas, Pelotas, 2017.

SAVEDRA, Monica Maria; MAZZELLI-RODRIGUES, Leticia. A língua pomerana em percurso histórico brasileiro: uma variedade (neu)autóctone. Working Papers em Linguística, v. 18, n. 1, p. 6-22, 2017. https://doi.org/10.5007/1984-8420.2017v18n1p6

SCHNEIDER, Aloi. Dicionário escolar conciso: português-pomerano / pomerischportugijsisch. Evangraf. Porto Alegre, 2019.

SCHULZ, Fritz. Provinz Pommern. Tradução de Felipe Bilharva da Silva. 2011. 1 mapa, color, $50 \mathrm{~cm}$ x $51 \mathrm{~cm}$. Escala 1: 2500000. 2018. Disponível em: https://www.pommerscher-greif.de/geographie/articles/kartographie.html. Acesso em: 30 ago. 2020. 


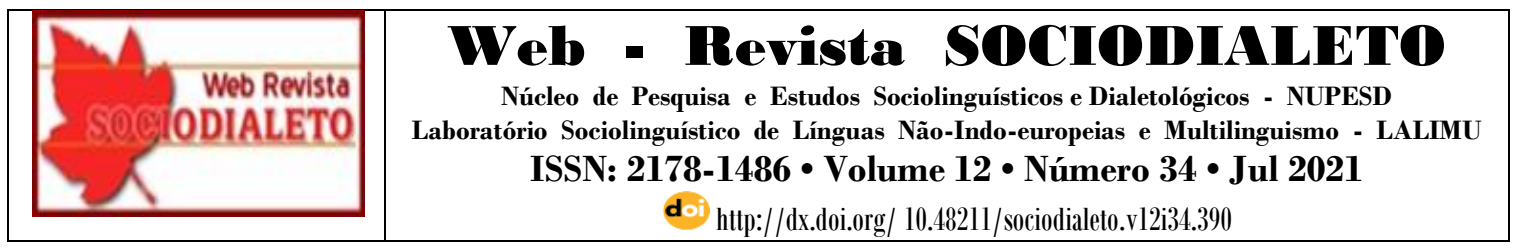

SCHRAMM, Renata Carpena. Falar mais de uma língua pode aumentar a criatividade? Um estudo cognitivo sobre o impacto do bilinguismo na atenção e na criatividade. 2015. 180 f. Tese (Programa de Pos-Graduacao em Letras) - Universidade Catolica de Pelotas, Pelotas, 2015.

SCHWARTZ, Douglas. Canguçu tem a $1^{\mathrm{a}}$ escola do RS com língua Pomerana incluída nas disciplinas. Canguçu Online. Disponível em: https://www.cangucuonline.com.br/noticias/cangucu/rs/tv-cangucu-online/videocangucu-tem-a-1a-escola-do-rs-com-lingua-pomerana-incluida-nasdisciplinas/?fbclid=IwAR1n3VJhiAvtotu_jlEuTyDAudWo96q8jsNyknNAbHScrk hHax9r3D2c. Acesso em: 23 nov. 2020.

SOUZA, Luana Cyntia. Revitalização de Línguas Minoritárias em Contextos Plurilíngues: O Pomerano em Contato com o Português. 2017. 130 f. Dissertação de Mestrado. Porto Alegre: Universidade Federal do Rio Grande do Sul, 2017.

STERIADE, Donca. Gestures and autosegments. In: BECKMAN, Mary; KINGSTON, John. (eds.) Papers in Laboratory Phonology. Cambridge University Press, 1990. p. 382-397. https://doi.org/10.1017/CBO9780511627736.021

TRESSMANN, Ismael. Dicionário Enciclopédico Pomerano-Português. Vitória: Gráfica e Encadernadora Sodré, 2006a.

TRESSMANN, Ismael. Upm Land - Up Pomerisch Språk. Vitória: Editora Sodré Ltda, 2006 b.

TRESSMANN, Ismael. O Pomerano: Uma Língua Baixo-Saxônica. Revista da FARESE, v. 1, p. 10-21, 2008.

VAHL, Mônica Strelow (2017). Motivações para a alternância de código portuguêspomerano entre alunos do Ensino Médio de Arroio do Padre - RS. 2017. 165 f. Dissertação (Mestrado) - Programa de Pós-Graduação em Letras, Centro de Letras e Comunicação, Universidade Federal de Pelotas, Pelotas, 2017.

VANDRESEN, Paulino. Contato lingüístico e bilingüismo em Arroio do Padre. MATZENAUER, Carmen L. B. et al. (orgs.) Anais do VII Encontro do Círculo de Estudos Linguísticos do Sul - CELSUL, 7, 2006, Pelotas. 1-6, 2006.

VANDRESEN, Paulino; Corrêa Adriane. O bilinguismo pomerano-português na região de Pelotas. Anais do VII Encontro do CELSUL - Círculo de Estudos Lingüísticos do Sul. Pelotas: EDUCAT. 1-14, 2008.

WEINREICH, Uriel. Languages in contact. The Hague: Mouton Publishers, 1963.

Recebido em: 28/04/2021 | Aprovado em: 22/05/2021. 